\author{
Justyna Wiktorowicz \\ Katedra Statystyki Ekonomicznej i Społecznej \\ Uniwersytet Łódzki \\ justynawiktorowicz@uni.lodz.pl

\section{WYDŁUŻENIE AKTYWNOŚCI ZAWODOWEJ CZY PRZEJŚCIE NA EMERYTURĘ? STUDIUM MIKROEKONOMICZNE}

\title{
WSTĘP
}

Starzenie się społeczeństw stanowi w ostatnich latach jedno z najważniejszych zjawisk kształtujących politykę społeczną zarówno w Polsce, jak i w innych krajach europejskich i pozaeuropejskich. Co istotne, coraz silniejszy jest trend odchodzenia od postrzegania tego zjawiska w kategoriach jedynie zagrożeń. Silver economy, zarządzanie wiekiem, lifelong learning to pojęcia, które coraz silniej zakorzeniają się w świadomości różnych interesariuszy rynku pracy i polityki społecznej. Wszystkie one nastawione są na jak najlepsze wykorzystanie potencjału osób w wieku okołoemerytalnym (wpisując się jednocześnie w koncepcję cyklu życia), ale i nowych potrzeb społecznych, jakie towarzyszą - z jednej strony - zwiększaniu udziału osób po 50. roku życia w społeczeństwie, a z drugiej zaś znacznej poprawie jakości ich życia. Prowadzone działania mają przyczynić się do poprawy jakości życia starszego pokolenia (osób w wieku emerytalnym, ale i przedemerytalnym), a także przynieść korzyści makroekonomiczne, wynikające m.in. z wydłużenia aktywności zawodowej (odsunięcie w czasie momentu przejścia na emeryturę).

Zarówno w Polsce, jak i w innych krajach europejskich, prowadzona jest obecnie polityka ukierunkowana na wydłużenie aktywności zawodowej. Realizowany od 2008 r. w Polsce program rządowy Solidarność Pokoleń. Działania dla zwiększenia aktywności zawodowej osób w wieku 50+ (dalej zwany Programem), zaktualizowany w końcu 2013 r., ma na celu osiągnięcie w perspektywie do 2020 r. wskaźnika zatrudnienia osób w wieku 55-64 lata na poziomie 50\% (Solidarność Pokoleń... 2008: 5). Przewidziano w nim pakiet działań dotyczących m.in. podniesienia efektywnego wieku emerytalnego (tj. rzeczywistego wieku przechodzenia na emeryturę) i zrównania wieku emerytalnego kobiet i mężczyzn (Podgórniak-Krzykacz, Przywojska 2011: 73-74). Obecnie, w przypadku mężczyzn, wiek przejścia na emeryturę 
jest wyraźnie niższy od ustawowego (pomimo jego formalnej, pięcioletniej różnicy dla kobiet i mężczyzn, sięga w rzeczywistości około 60 lat dla obu płci). Tym bardziej interesujące są motywy podejmowania decyzji o dezaktywizacji zawodowej lub wprost przeciwnie - o kontynuacji pracy zawodowej również po przekroczeniu ustawowego wieku emerytalnego.

Analiza, której wyniki zaprezentowane zostały w niniejszej pracy, koncentruje się na stronie podażowej rynku pracy, a jej ujęcie ma charakter mikroekonomiczny. Jako główny cel pracy przyjęto wskazanie czynników sprzyjających wydłużaniu okresu aktywności zawodowej Polaków, ale jedynie z perspektywy jednostkowej, tj. uwarunkowań indywidualnych decyzji osób w wieku okołoemerytalnym. Badana problematyka jest oczywiście dużo bardziej skomplikowana i wielowymiarowa, a $\mathrm{z}$ drugiej strony - coraz silniej zakorzeniona w polityce społecznej większości krajów, w tym - od kilku lat - również Polski. Zagadnienia te zostaną jednak w tym miejscu pominięte.

Prowadzone analizy pozwolą uzyskać odpowiedzi na następujące pytania badawcze:

- Jakie cechy różnicują aktywność zawodową „starszych” Polaków?

- Jak na swoją przyszłość zawodową, tj. jej wydłużenie bądź dezaktywizację, zapatrują się pracujący w wieku okołoemerytalnym?

- Jakie są stymulanty i destymulanty wydłużania aktywności zawodowej pracujących (zwłaszcza w perspektywie jednostkowej)?

- Co mogłoby skłonić pracujących w wieku okołoemerytalnym do opóźnienia przejścia na emeryturę?

Analiza empiryczna umożliwiła weryfikację następującej hipotezy badawczej: podejście do wydłużania własnej aktywności zawodowej przez osoby w wieku okołoemerytalnym jest zróżnicowane, a warunkuje je zwłaszcza sytuacja życiowa (w szczególności stan zdrowia i konieczność sprawowania opieki nad członkami rodziny) oraz kompetencje pracujących.

\section{MATERIAŁ BADAWCZY I METODY}

Głównym źródłem analizowanych danych są wyniki ogólnopolskiego badania „Diagnoza obecnej sytuacji kobiet i mężczyzn 50+ na rynku pracy w Polsce” (dalej: Diagnoza), przeprowadzonego w 2012 r. przez pracowników Uniwersytetu Łódzkiego w ramach projektu „Wyrównywanie szans na rynku pracy dla osób 50+”, realizowanego wspólnie z Centrum Rozwoju Zasobów Ludzkich (Lider Partnerstwa). Projekt ten współfinansowany jest ze środków Unii Europejskiej w ramach Europejskiego Funduszu Społecznego. Diagnoza miała na celu ocenę sytuacji Polaków w wieku okołoemerytalnym na rynku pracy. Stanowiła ona wielowątkowe badanie, obejmujące zarówno komponent jakościowy, jak i ilościowy, a z drugiej strony - różne grupy interesariuszy: osoby w wieku okołoemerytalnym (rozumianym jako 
przedział wieku 45-69 lat), pracodawców, wybrane instytucje rynku pracy, wybrane jednostki pomocy i integracji społecznej oraz NGO'sy. Prezentowane wyniki Diagnozy opierają się na badaniu osób w wieku 45-69 lat $(\mathrm{n}=3200$; średni błąd estymacji na poziomie $1,8 \%$; przyjęte zasady doboru próby zapewniają jej reprezentatywność). Badanie przeprowadzono metodą CAPI (wywiady kwestionariusze wspomagane komputerowo). Szczegółowe informacje na temat metodyki badań Diagnozy, w tym wzory wykorzystanych kwestionariuszy, można znaleźć w Aneksie metodologicznym, stanowiącym załącznik do raportu końcowego z Diagnozy (Krzewińska, Wiktorowicz 2013) ${ }^{1}$.

W ramach Diagnozy przebadano zarówno osoby, które przeszły już na emeryturę, jak i te pracujące, bezrobotne oraz inne grupy nieaktywne zawodowo, przy czym W niniejszym artykule analizę ograniczono do osób pracujących. W pracy wykorzystano głównie niepublikowane, opracowane dla potrzeb niniejszego artykułu, wyniki badań Diagnozy, a także niektóre wyniki analiz prezentowane w raportach końcowych z badań projektu (Kryńska, Krzyszkowski, Urbaniak, Wiktorowicz (red.) 2013; Kryńska, Szukalski (red.) 2013).

Ilościowa analiza wyników Diagnozy przeprowadzona została z wykorzystaniem testów istotności różnic (pomiar większości analizowanych zmiennych realizowany był na skali nominalnej dlatego wykorzystano test niezależności chi-kwadrat lub dokładny test Fishera; w nielicznych przypadkach - ANOVA). Dodatkowo, zastosowana została regresja logistyczna - metoda pozwalająca na oszacowanie prawdopodobieństwa dłuższej aktywności zawodowej, w tym wskazania czynników determinujących taką decyzję. Obliczeń wykonano wykorzystując oprogramowanie IBM SPSS Statistics v. 21.0.

\section{SYTUACJA ZAWODOWA POLAKÓW W WIEKU 45-69 LAT}

Badanie osób w wieku 45-69 lat, przeprowadzone w ramach Diagnozy, pozwoliło, po pierwsze, na dokonanie oceny sytuacji zawodowej osób należących do tej populacji. Jest ona zróżnicowana według płci, grup wieku, poziomu wykształcenia, stanu zdrowia i innych cech demograficznych (tablica 1). Prawie połowę populacji stanowią osoby nadal pracujące (najemnie, na własny rachunek lub we własnym gospodarstwie rolnym, przy czym najliczniejszą grupę stanowią pracownicy najemni, stanowiący 36,7\% całej populacji w wieku 45-69 lat), ok. 27\% jest już na emeryturze, kolejne $18 \%$ jest nieaktywna zawodowo z powodu nabycia uprawnień rentowych lub innych okoliczności (zajmowania się domem, utrzymywania się z innych niezarobkowych źródeł). Biorąc pod uwagę tematykę pracy, zwróćmy uwagę na udział pracujących w poszczególnych podpopulacjach. Pracujący stanowią

1 Wersja elektroniczna obu cytowanych raportów (wraz $\mathrm{z}$ aneksami) dostępna jest na http:/www.50plus.gov.pl. 
ponad połowę mężczyzn i $40 \%$ kobiet, a ich udział w danej subpopulacji maleje Z wiekiem (71\% dla grupy 45-49 lat wobec 14,9\% dla będących w wieku 60-64 lata i zaledwie 1,6\% dla grupy w wieku 65-69 lat). Odsetek pracujących jest wyższy dla osób o wyższym poziomie wykształcenia (sytuacja ta pozostaje niezmienna od wielu lat, co wyraźnie potwierdzają dane BAEL). Z jednej strony, osoby z wykształceniem podstawowym lub ewentualnie z gimnazjalnym (choć ci są nieliczni) - są mniej zainteresowane kontynuowaniem pracy zawodowej w okresie poprzedzającym emeryturę, częściej i dłużej pozostają bezrobotnymi, z drugiej jednak, należy zwrócić uwagę na generalnie słabsze wykształcenie osób ze starszych grup wieku. Zgodnie z oczekiwaniami, pracujących jest też znacznie więcej wśród osób o lepszej kondycji zdrowotnej - wśród osób oceniających swoje zdrowie dobrze jak na swój wiek (a więc też z pewnością niepozbawionych dolegliwości chorobowych) dwie na trzy osoby to pracujący, podczas gdy wśród oceniających je źle - tylko $16 \%$. Mniejsze znaczenie odgrywa w tej kwestii miejsca zamieszkania, choć odsetek pracujących jest najwyższy w dużych miastach $(51 \%$, a więc o prawie $10 \mathrm{pkt}$ proc. więcej niż w miastach średniej wielkości), na terenie powiatów typu C $(48,4 \%)$.

W świetle badań projektu „Bilans Kapitału Ludzkiego”, osoby powyżej 50. roku życia stanowią jedyną grupę wieku, w której z roku na rok obserwuje się wyraźnie mniejszy udział biernych zawodowo i wyraźnie większy wskaźnik zatrudnienia (choć także w tej kategorii rośnie odsetek bezrobotnych); podobne zmiany, choć znacznie słabiej, zarysowują się w grupie wieku 45-54 lata (Czarnik, Turek 2014: 23). Potwierdzają to również dane BAEL - w 2013 r. współczynnik aktywności zawodowej wynosił średniorocznie: dla osób w wieku 45-54 lata - 80,4\%, dla osób w wieku 55-59/64 lata - 54\%, zaś dla tych w wieku 60/65 lat i więcej - 6,6\%. W III kwartale 2014 r. było to już - odpowiednio - 81,4\%, 56,2\% i 7,3\%. Poziom tego wskaźnika jest nieco wyższy dla mężczyzn niż kobiet, choć sytuacja w tym zakresie coraz bardziej się wyrównuje. Wskaźnik zatrudnienia kształtował się dla kolejnych wymienianych grup wieku na następującym poziomie: średnio w $2013 \mathrm{r}$. - 74,1\%, 49,7\% i 6,4\%, w III kw. 2014 r. - 76,3\%, 52,6\%, 7,2\%. Dla porównania, w 2008 r. średnioroczny poziom wskaźnika zatrudnienia sięgał - odpowiednio - 66,6\%, 24,5\% i 5\%, a współczynnika aktywności zawodowej - 76,1\%, 39,4\% i $5,9 \%$. Dane te potwierdzają znaczny wzrost aktywności zawodowej osób w wieku przedemerytalnym.

Analizując dane BAEL należy też podkreślić, że w przypadku osób w wieku $55+$ udział pracujących $w$ niepełnym wymiarze jest najwyższy $(15,2 \%$, analogiczny poziom wskaźnika dotyczy tylko osób w wieku 15-24 lata - 14,7\%, wobec średniej 7,7\%). 5,4\% pracujących w wieku 55+ ma więcej niż jedno miejsce pracy (dla osób w wieku 45-54 lata wskaźnik ten kształtuje się na poziomie analogicznym do osób w wieku 35-44 lata - 7,9\%). Dane te potwierdzają, z jednej strony większą skłonność do korzystania z elastycznych form zatrudnienia u schyłku kariery zawodowej, z drugiej zaś strony wskazują na ciągle dość znaczne zainteresowanie dywersyfikacją źródeł dochodu również w przypadku tej grupy Polaków. 
Wydhużenie aktywności zawodowej czy przejście na emeryturę?...

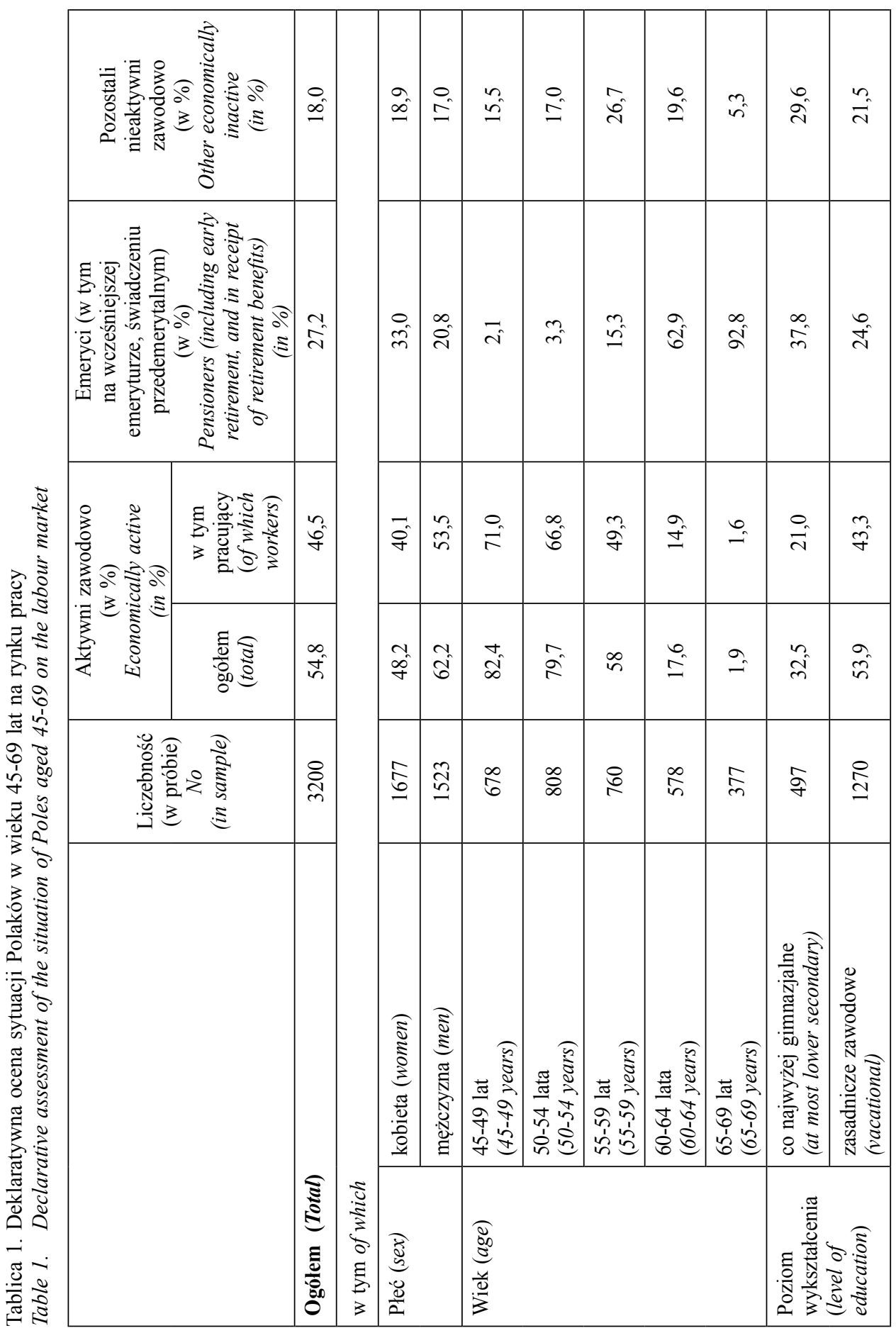




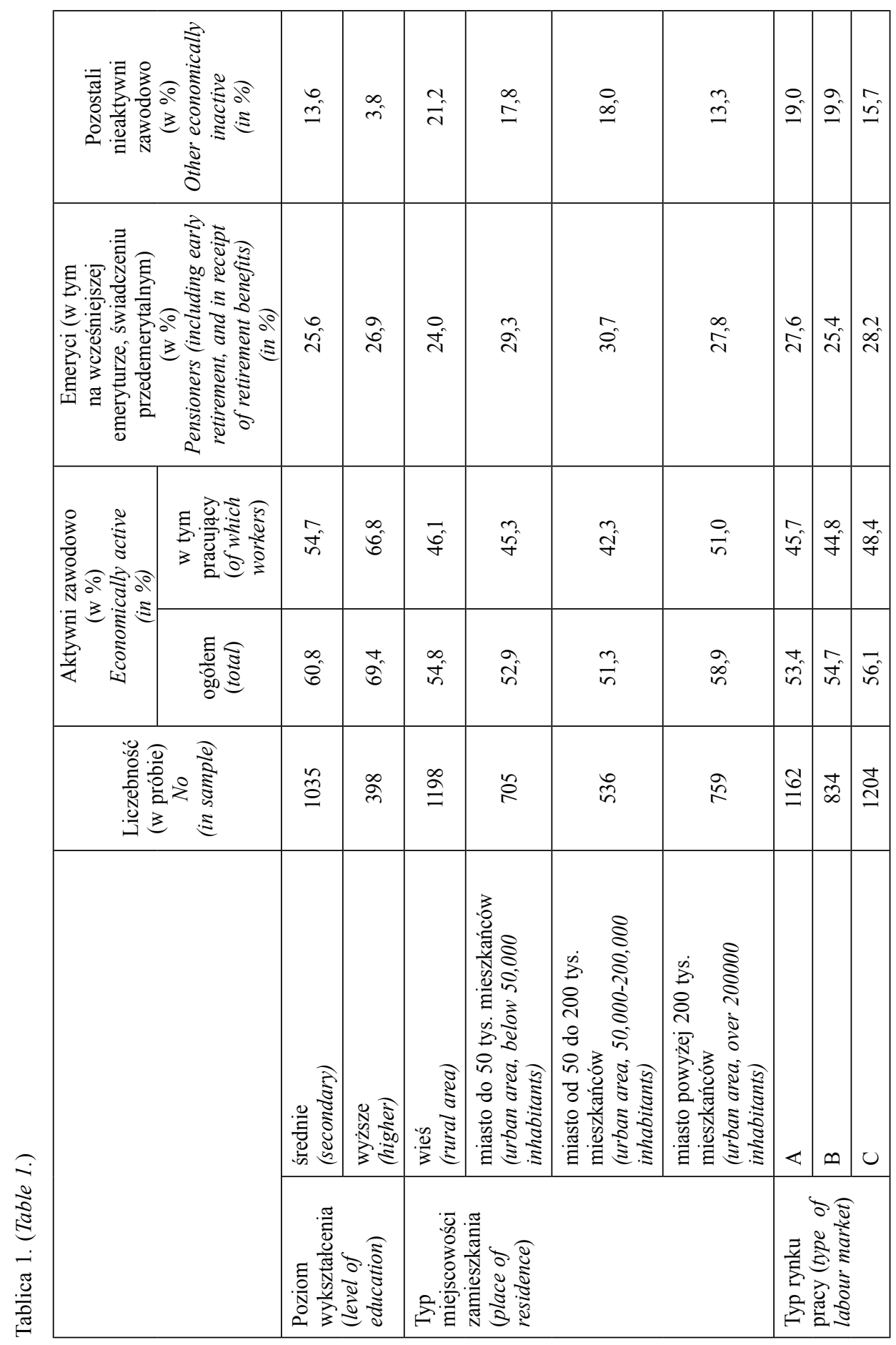


Wydtużenie aktywności zawodowej czy przejście na emeryturę?...

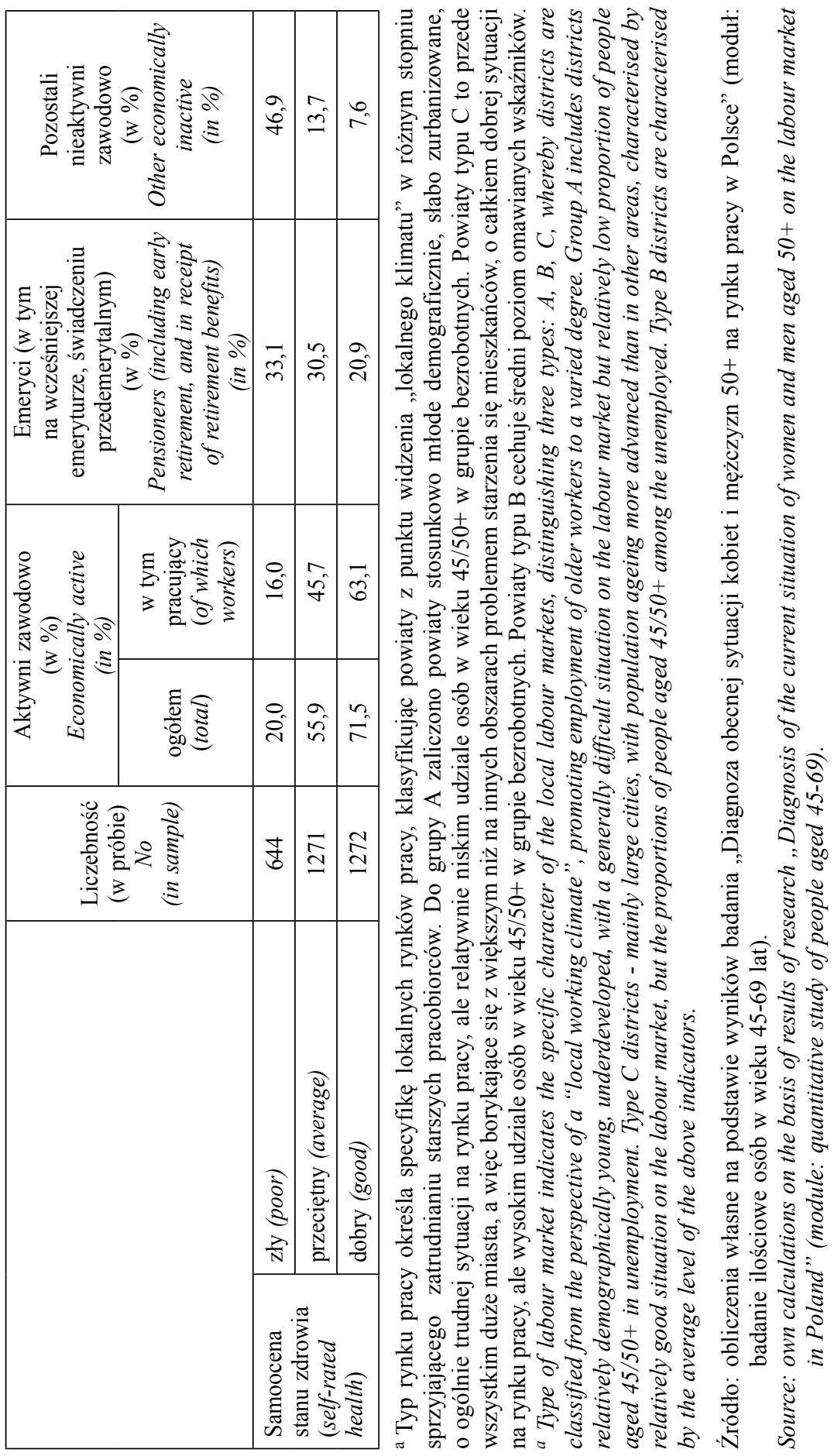




\section{PLANY DOTYCZĄCE DALSZEJ AKTYWNOŚCI ZAWODOWEJ PRACUJĄCYCH W WIEKU $45+$}

Oprócz oceny sytuacji zawodowej osób należących do tej populacji, badanie osób w wieku 45-69 lat przeprowadzone w ramach Diagnozy, uwzględniało również perspektywiczne ujęcie kariery zawodowej Polaków. W kwestionariuszu znalazło się m.in. pytanie „Myśląc o swojej obecnej pracy, czy chciałby/aby Pan/i odejść na emeryturę tak szybko, jak to możliwe?”, na które pracujący mogli udzielić odpowiedzi na pięciostopniowej skali Likerta (od zdecydowanie nie po zdecydowanie tak). Analizując rozkład odpowiedzi na to pytanie (zmienna PlZaw), można ocenić skłonność pracujących do kontynuowania własnej kariery zawodowej - osoby, które wybrały odpowiedź ,zdecydowanie tak” lub „raczej tak” wykazują skłonność do dezaktywizacji zawodowej, zaś osoby, które wybrały odpowiedź ,zdecydowanie nie” lub „raczej nie” wykazują skłonność do wydłużania swojej aktywności zawodowej.

Wykres 1. Opinia pracujących na temat chęci odejścia na emeryturę tak szybko, jak to jest możliwe według płci i wieku $(\mathrm{w} \%)^{1)}$

Figure 1. Willingness to retire as soon as possible in opinion of workers aged $45+$ by sex and age groups (in \%)
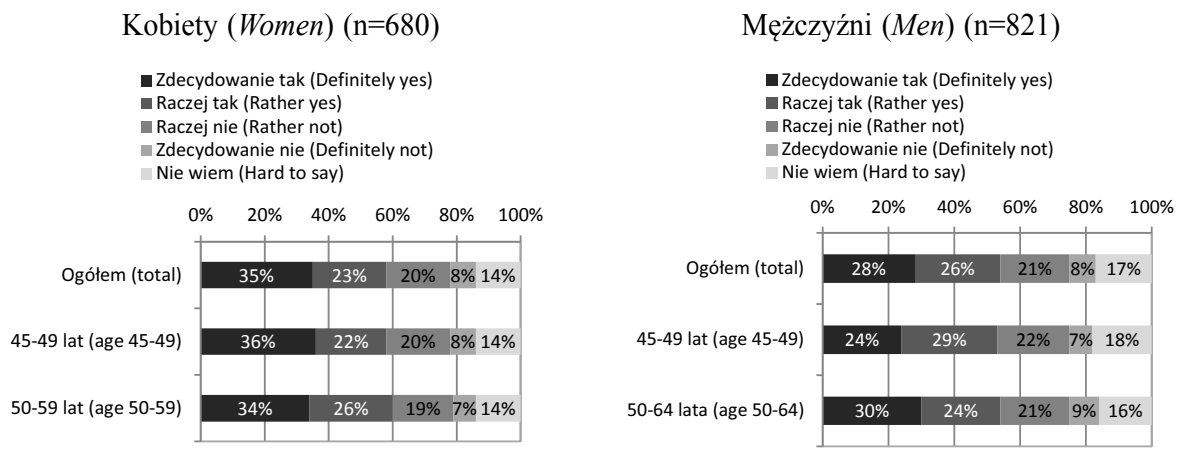

1) Pominięto osoby w wieku 60/65-69 lat z uwagi na niewielką liczbę pracujących (w obrębie próby: 23 kobiety, 10 mężczyzn)

1) Workers aged 60/65-69 have been omitted because of low numbers (in the sample: 23 women, 10 men).

Źródło: opracowanie własne na podstawie wyników badania „Diagnoza obecnej sytuacji kobiet i mężczyzn 50+ na rynku pracy w Polsce" (moduł: badanie ilościowe osób w wieku 45-69 lat).

Source: own elaboration on the basis of results of research „Diagnosis of the current situation of women and men aged 50+ on the labour market in Poland" (module: quantitative study of people aged 45-69).

Osoby w wieku 45-69 lat, które nadal pracują zawodowo, zwykle (w ponad 50\%) planują przejście na emeryturę tak szybko, jak to tylko będzie możliwe - aż 31\% 
zdecydowanie wyraża taką opinię, kolejne 24,5\% raczej chce tak uczynić. Z drugiej strony, warto podkreślić, że prawie $30 \%$ pracujących nie podziela tej opinii, kolejne $16 \%$ nie jest zdecydowanych. Daje to szerokie pole do działań, które utrwaliłyby pozytywne podejście osób w wieku 45+ do własnej aktywności zawodowej, a także służyłyby przekonaniu niezdecydowanych. Zainteresowanie odejściem na emeryturę tak szybko, jak to będzie możliwe, jest przy tym większe w przypadku kobiet niż mężczyzn (różnice te nie są jednak statystycznie istotne $-\mathrm{p}=0,085^{2}$ ) - rys. 1. Daje się przy tym zauważyć, że im bliżej wieku emerytalnego, tym mniej chętnie chcą przejść na emeryturę kobiety, i tym bardziej zdecydowanie - mężczyźni (różnica wskazań mężczyzn w wieku 50-64 lat w stosunku do tych w wieku 45-49 lat sięga ok. 6 pkt proc.). Odsetek niemających w tym zakresie wyrobionego zdania jest niezależny od wieku (odpowiednio 14\% dla kobiet i 17-18\% dla mężczyzn). Co ciekawe, w przypadku kobiet w wieku 60-69 lat $(n=23)$ prawie połowa nie zamierza przejść szybko na emeryturę, jeśli chodzi o mężczyzn - wskazało tak zaledwie trzech na dziesięciu badanych w wieku 65+.

Biorąc pod uwagę inne cechy, można wskazać, że w przypadku pracujących w wieku 45+ największą skłonność do wydłużenia aktywności zawodowej wyrażają ${ }^{3}$ :

- mieszkańcy największych (powyżej 200 tys. mieszkańców) i najmniejszych miast (odpowiednio 48,9\% i 39,1\% nie myśli o wczesnej dezaktywizacji); na drugim biegunie są mieszkający na wsi - analogiczną opinię wyraziła tylko co czwarta osoba $(\mathrm{p}<0,001)$;

- mieszkańcy powiatów silnie zurbanizowanych, o trudnej sytuacji osób w wieku $45+$, ale stosunkowo niskiej ogólnej stopie bezrobocia (rynek typu C) - 41\% wskazań wobec ok. 30\% dla pozostałych obszarów $(\mathrm{p}=0,002)$;

- osoby o lepszym stanie zdrowia $(\mathrm{p}<0,001)$ - prawie połowa osób o dobrym (jak na swój wiek) stanie zdrowia (wobec zaledwie 7\% oceniających swoje zdrowie jako złe) nie chce przejść na emeryturę jak tylko będzie to możliwe;

- osoby, które nie mają obowiązków związanych ze sprawowaniem opieki nad wnukami w wieku do 7 lat i/lub trwale chorymi rodzicami (ok. 35\%; p<0,001);

- pracujący na własny rachunek $(53,1 \%)$, najrzadziej zaś - rolnicy $(18,7 \%)$ $(\mathrm{p}<0,001)$; spośród zatrudnionych, o kontynuacji pracy zawodowej myślą najczęściej zatrudnieni na podstawie umowy o pracę na czas nieokreślony $(35,3 \%$ wobec $29 \%$ zatrudnionych na czas określony i $27,5 \%$ pracujących na podstawie umowy cywilnoprawnej);

- osoby, które kiedykolwiek prowadziły działalność gospodarczą - 41,3\% wobec $32,4 \%$ w przypadku niemających takich doświadczeń $(p=0,008)$;

2 Zastosowano test niezależności chi-kwadrat. Różnice uznaje się za statystycznie istotne, gdy $\mathrm{p}<0,05$.

3 O ile nie zaznaczono inaczej, $\mathrm{p}$ - prawdopodobieństwo w teście chi-kwadrat lub, alternatywnie, w dokładnym teście Fishera. 
- osoby bardziej otwarte na zmianę miejsca pracy, tj. mające w swojej karierze zawodowej doświadczenia $\mathrm{z}$ większą liczbą pracodawców $\left(\mathrm{p}=0,049^{4}\right)$;

- zatrudnieni na stanowiskach kierowniczych $(59,6 \%)$ lub na stanowiskach nierobotniczych (ok. 45\%); zupełnie inne podejście mają osoby pracujące na stanowiskach robotniczych $-69,5 \%$ robotników niewykwalifikowanych (w tym aż $84,7 \%$ w kobiet) i $63 \%$ robotników wykwalifikowanych chce jak najszybciej przejść na emeryturę ( $<<0,001)$; znaczące jest też to, że co piąta osoba zajmująca stanowisko kierownicze nie ma w tym względzie wyrobionego zdania;

- pracujący w sektorach „administrowanie i działalność wspierająca”, „obsługa rynku nieruchomości”, „,informacja i komunikacja”, „działalność profesjonalna, naukowa i techniczna" (odsetek powyżej 50\%), „działalność finansowa i ubezpieczeniowa”, ,zakwaterowanie i gastronomia”, „edukacja” (40-50\%); na przeciwległym biegunie są pracujący w rolnictwie, przemyśle, górnictwie i hutnictwie (odsetki są ponad dwukrotnie niższe); z uwagi na niewielkie liczebności większości wymienianych podprób, wnioski te należy traktować jedynie sygnalnie;

- warunki pracy odgrywają również znaczenie $(\mathrm{p}<0,001)$ - o kontynuowaniu zatrudnienia myślą najczęściej osoby pracujące w pozycji siedzącej (wykonujące np. pracę biurową) - 43,4\% wskazań; z kolei o przejściu na emeryturę myślą zwłaszcza osoby wykonujące pracę związaną z wysiłkiem fizycznym, pracę fizyczną wymagającą noszenia ciężkich przedmiotów (ok. 65\%), z drugiej strony - osoby wykonujące najcięższą pracę są równie skłonne do kontynuowania zatrudnienia, jak osoby wykonujące lekkie fizycznie prace (np. prace biurowe) - ok. 35\% wskazań; jak wynika $\mathrm{z}$ bardziej pogłębionych analiz, jest to w dużej mierze efektem zadowolenia z pracy, spełnienia zawodowego tych osób, które robią to, co lubią;

- osoby, które nie muszą dojeżdżać do pracy poza miejscem zamieszkania $(36,2 \%$ wobec $29,5 \%$, których miejsce pracy jest poza miejscem zamieszkania $(\mathrm{p}=0,036))$;

- osoby lepiej wykształcone $(\mathrm{p}<0,001)$, zwłaszcza te $\mathrm{z}$ wykształceniem wyższym (15,7\% pracujących $\mathrm{z}$ tej grupy zdecydowanie nie planuje przejść na emeryturę tak szybko, jak to będzie możliwe), podczas gdy dla osób słabiej wykształconych, tj. legitymujących się wykształceniem niepełnym podstawowym, podstawowym lub - znacznie rzadziej deklarowanym - wykształceniem gimnazjalnym (zaledwie 1,9\% osób planuje odłożyć w czasie decyzję o przejściu na emeryturę); z drugiej strony, znacznie częściej zdecydowanie chcą przejść na emeryturę osoby o niższym poziomie wykształcenia ( $48,6 \%$ dla osób z wykształceniem co najwyżej gimnazjalnym wobec 19,4\% z wyższym);

- osoby, które są zadowolone z aktualnego miejsca pracy pod względem zarobków, stabilności zatrudnienia $\mathrm{w}$ miejscu pracy, organizacji i fizycznych warunków pracy, rodzaju powierzanych zadań, możliwości godzenia pracy zawodowej z obo-

\footnotetext{
$4 \mathrm{p}$ - prawdopodobieństwo $\mathrm{w}$ teście $\mathrm{F}$ analizy wariancji.
} 
Wydtużenie aktywności zawodowej czy przejście na emeryturę?...

wiązkami domowymi i rodzinnymi, stosunków z przełożonym i współpracownikami, uznania ze strony przełożonego, uczestnictwa w szkoleniach zawodowych (mniej więcej połowa wskazań); z kolei wśród osób bardzo niezadowolonych odsetek ten przyjmuje dla poszczególnych wymienianych powyżej właściwości miejsca pracy wartości od 10 do $20 \%$;

- osoby o wyższych kompetencjach „twardych” - mniej więcej połowa tych, którzy wskazują na wysokie umiejętności obsługi komputera (wobec 14\% wskazujących na ich brak), a także ponad połowa znających języki obce (wobec 22\% oceniających tę umiejętność na poziomie zerowym lub bardzo niskim) i 38,2\% posiadających prawo jazdy (wobec 24,8\% niemających takich uprawnień) nie chce jak najszybciej przejść na emeryturę; podobnie znaczące różnice odnotowuje się w przypadku samooceny kompetencji „miękkich” $(\mathrm{p}<0,001)$;

- osoby dalej aktywne edukacyjne - 48,2\% z nich (wobec 32,4\% tych, którzy w ciągu ostatnich 2 lat nie podejmowali edukacji) myśli o dłuższej aktywności zawodowej $(\mathrm{p}<0,001)$;

- osoby zajmujące się działalnością społeczną $(44,6 \%)(p=0,068)$.

Powyższe wnioski w dużej mierze potwierdzają, ale też w pewnym zakresie uzupełniają wyniki dotychczasowych prac badawczych. Analizując przyczyny dezaktywizacji zawodowej, a tym samym bariery wydłużania aktywności zawodowej wskazuje się, że jest ich wiele, a ich jednoznaczna identyfikacja jest problematyczna. Co więcej, natura wpływających na to zjawisko czynników ma charakter zarówno jednostkowy, jak i systemowy, zaś ich istota zmienia się wraz ze zmianami zachodzącymi w całej gospodarce. W świetle dotychczasowych badań, wśród głównych przyczyn dezaktywizacji zawodowej (a tym samym barier wydłużania aktywności zawodowej) należy wymienić:

\section{Uwarunkowania na poziomie makro- $i$ mezoekonomicznym}

- ogólnie trudna sytuacja na rynku pracy lub niestabilność tego rynku (brak miejsc pracy w miejscu zamieszkania, zwłaszcza w miejscowościach oddalonych od większych miast oraz stała obawa utraty pracy popychają ludzi do szybszego przejścia na emeryturę ze względu na to, iż jest ona czymś stałym i pewnym, daje poczucie stabilizacji, jednocześnie nie wyklucza całkowicie z rynku pracy) (Sztanderska 2008: 19);

- zachęty do przechodzenia na emeryturę tkwiące w systemie ubezpieczeń społecznych: niestabilność prawa (zmiany dotyczące zasad przechodzenia na emeryturę powodują, że ludzie chętniej skłaniają się ku decyzji opuszczenia rynku pracy w obawie przed zmianą sytuacji na mniej korzystną dla siebie), dostępność pracy w szarej strefie, a także utrzymująca się relacja świadczeń społecznych i płac (zwłaszcza w przypadku prac niskopłatnych, nie wymagających wysokich kwalifikacji) (Giza-Poleszczuk 2008: 129-130), możliwość łączenia emerytury z pracą (Sztanderska 2008: 19); jednocześnie należy podkreślić znaczne ustabilizowanie w tym zakresie - poprzez ograniczenie uprawnień do wcześniejszej emerytury 
(zniesienie ich w systemie powszechnym uprawnień emerytalnych), stopniowe wyrównanie wieku emerytalnego kobiet i mężczyzn oraz jego podniesienie do 67 lat (Bukowski 2010: 29-30), a tym samym osłabienie znaczenia pierwszego z wymienionych czynników; efekt ten potwierdzają wyniki badań Diagnozy Spotecznej - prawdopodobieństwo dezaktywizacji z powodu przejścia na emeryturę maleje szczególnie w przypadku bezrobotnych (tendencja ta jest słabsza dla pracujących - Czapiński, Panek (red.) 2013: 135);

- negatywny stosunek pracodawców do zatrudniania starszych pracowników, ale też utrzymania zatrudnienia, zwłaszcza w sytuacji rosnącej dysproporcji między obniżającą się produktywnością a zarobkami starszych pracowników (Gurria 2008; Cohen i in. 2011: 25; Munnel, Sass 2008; Perek-Białas i in. 2010: 41; Zawadzki 2009: 11-17; Dolny 2009: 96-99; Szaban 2010; Karpowicz 2010: 19);

\section{Uwarunkowania na poziomie jednostkowym}

- bariery psychologiczne, w tym zwłaszcza brak motywacji, niski etos pracy, niskie poczucie własnej wartości, brak właściwych nawyków w środowisku pracy w przypadku osób wychodzących z długotrwałego bezrobocia (Determinanty... 2010: 13, 47-49);

- cechy demograficzne, a w szczególności płeć (kobiety wciąż podlegają silniejszej presji na pozostawanie bez zatrudnienia w przypadku pojawiających się konieczności świadczenia usług dla rodziny, jak opieka nad dziećmi, obowiązki domowe, opieka nad chorymi, co skłania je do wcześniejszej dezaktywizacji zawodowej), poziom wykształcenia (wyższy poziom wykształcenia, bez względu na pojawiające się inne ograniczenia, zwiększa szansę na podjęcie zatrudnienia), miejsce zamieszkania (co wiąże się z dostępnością ofert pracy), wiek (Woszczyk (red.) 2011: 26; Silcock 2012; Contreras i in. 2013; Humphrey i in. 2003: 52; Chłoń-Domińczak 2009: 7-9);

- stan zdrowia (zwykle pogarszający się z wiekiem), wyczerpanie fizyczne i psychiczne (Rzechowska 2010: 44; Maitland 2010: 7-8; Szubert, Sobala 2005);

- zdezaktualizowane kwalifikacje zawodowe (Gurria 2008);

- pozycja zawodowa - dłuższą aktywność zawodową planują zwłaszcza menedżerowie i specjaliści oraz pracujący na własny rachunek, zatrudnieni na umowę o pracę na czas nieokreślony, cieszący się uznaniem ze strony współpracowników i przełożonych (Silcock 2012; Contreras i in. 2013; Summary ... 2012; Humphrey i in. 2003: 52); z drugiej strony, w świetle Diagnozy Społecznej w latach 2009-2013 wśród osób w wieku przedemerytalnym największy spadek aktywności zawodowej miał miejsce w przypadku wyższych urzędników i kierowników (Kotowska i in. 2014: 32);

- słabe kompetencje ICT - zgodnie $\mathrm{z}$ formułowaną w gerontologii teorią modernizacji, szybkie zmiany w zakresie nowych technologii i sposobów komunikowania się powodują, że nienadążający za nimi starszy pracownik, w sytuacji narastającej presji wycofuje się (Szukalski 2006); 
- sytuacja rodzinna zarówno związana z negatywnymi (choroba lub niepełnosprawność członka rodziny), jak i pozytywnymi aspektami życia - okres średniej dorosłości sprzyja często pogłębieniu i odkrywaniu nowych wymiarów relacji małżeńskiej (co stymuluje chęć przejścia na emeryturę w tym samym czasie, co współmałżonek), rozpoczyna się pełnienie ról dziadków (Rzechowska 2010: 46; Raport. Starzejace.... 2011: 7; Kotowska, Wóycicka 2008);

- chęć samorealizacji pozazawodowej.

Biorąc pod uwagę dotychczasowe ustalenia, podjęto próbę budowy modelu analitycznego, który służył wskazaniu czynników sprzyjających dłuższej aktywności zawodowej. Badając wydłużanie okresu aktywności zawodowej, w dalszym ciągu analizę ograniczano do populacji pracujących. Tym samym model nie służył wyjaśnieniu prawdopodobieństwa ,bycia pracującym” (zmienną wynikową nie była rzeczywista sytuacja na rynku pracy osób w wieku okołoemerytalnym). Ocenie poddano zapatrywania pracujących na własną, przyszłą karierę zawodową, a konkretnie stosunek do możliwie szybkiego przejścia na emeryturę. Dla potrzeb analiz, oryginalna zmienna (PlZaw), mierzona - jak zaznaczano - na pięciostopniowej skali Likerta, została przekształcona do postaci zero-jedynkowej (EWL), gdzie 1 przypisano wówczas, gdy wybrana została odpowiedź ,zdecydowanie nie” lub „raczej nie”. Z uwagi na zero-jedynkowy charakter zmiennej wynikowej $E W L$, parametry modelu szacowano metodą największej wiarygodności, konstruując równanie regresji logistycznej.

$\mathrm{Na}$ liście potencjalnych zmiennych objaśniających znalazły się cechy charakteryzujące demograficznie osoby w wieku 45+, a także zmienne charakteryzujące sytuację zawodową i „okołozawodową”. Biorąc pod uwagę wnioski z omówionych wcześniej badań, ale też zakres (a tym samym dostępność) danych pozyskanych w ramach Diagnozy, wśród zmiennych objaśniających uwzględniono:

$\mathrm{X}_{1}-$ płeć,

$\mathrm{X}_{2}-$ wiek (pięcioletnie grupy wieku),

$\mathrm{X}_{3}$ - klasa miejscowości zamieszkania,

$\mathrm{X}_{4}$ - poziom wykształcenia,

$\mathrm{X}_{5}$ - samoocena stanu zdrowia,

$\mathrm{X}_{6}-$ sprawowanie opieki (zarówno nad wnukami, starszymi rodzicami, jak i innymi osobami zależnymi),

$\mathrm{X}_{7}$ - obecny status na rynku pracy (przynależność do jednej z kategorii pracujących - zatrudnieni, pracujący na własny rachunek, rolnicy),

$\mathrm{X}_{8}-$ łączny staż pracy,

$\mathrm{X}_{9}$ - liczba miejsc pracy w całym życiu,

$\mathrm{X}_{10}$ - liczba miejsc pracy po 45 . roku życia,

$\mathrm{X}_{11}$ - typ rynku pracy,

$\mathrm{X}_{12}$ - podejmowanie aktywności edukacyjnej w ciągu ostatnich 2 lat,

$\mathrm{X}_{13}$ - posiadanie doświadczeń w prowadzeniu własnej działalności gospodarczej,

$\mathrm{X}_{14}$ - podejmowanie działalności społecznej.

Wyniki estymacji modelu zaprezentowano w tablicy 2. 


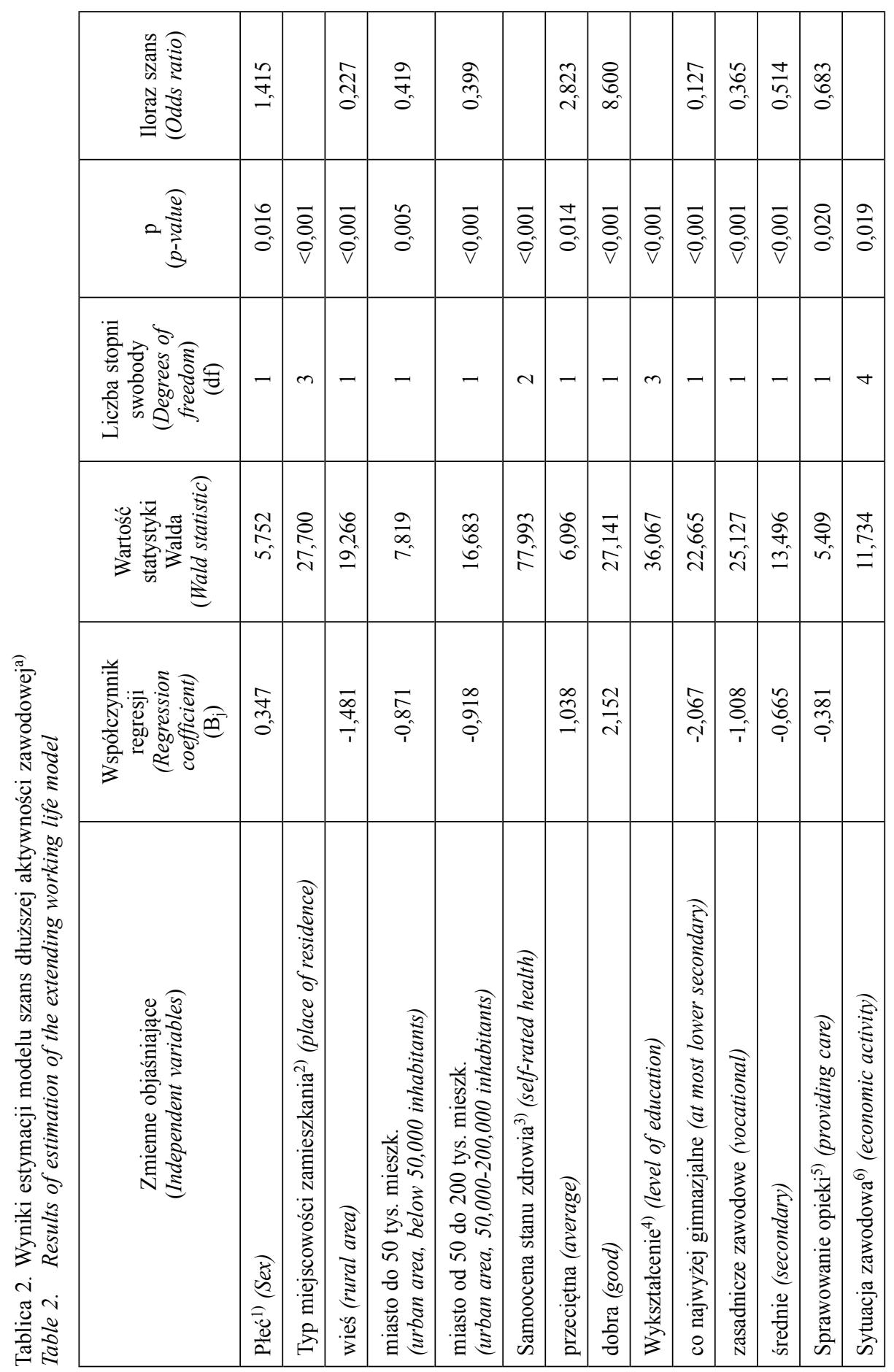


Wydtużenie aktywności zawodowej czy przejście na emeryturę?...

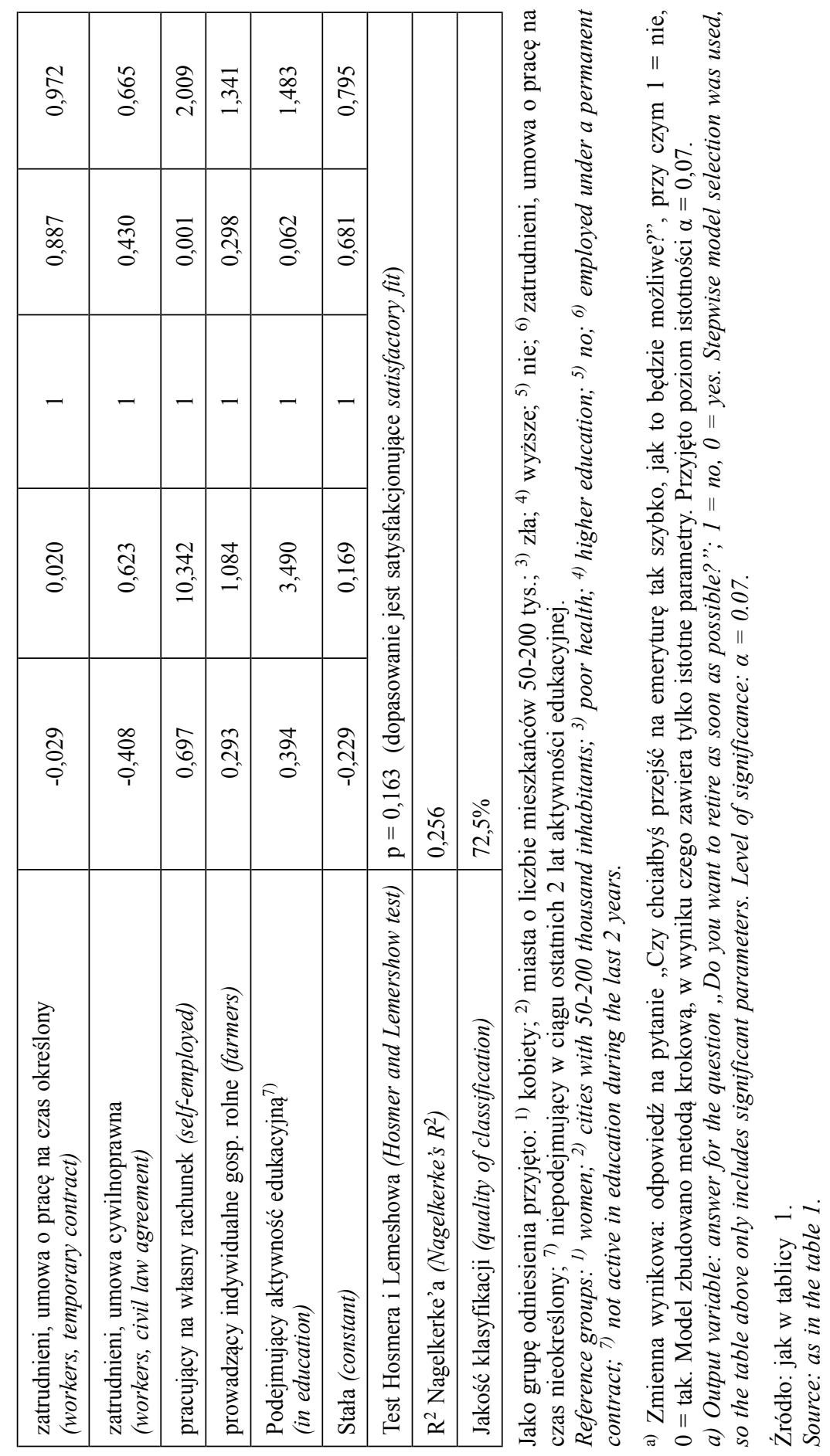


Spośród przyjętych wstępnie zmiennych, pozytywne nastawienie do wydłużania własnej aktywności zawodowej jest (ceteris paribus) istotnie (w sensie statystycznym) powiązane z taki czynnikami, jak:

- płeć - w przypadku pracujących mężczyzn szansa późniejszej dezaktywizacji zawodowej jest prawie 1,5-krotnie wyższa niż dla kobiet;

- klasa i wielkość miejscowości - w porównaniu z dużymi miastami, szansa dłuższej aktywności zawodowej jest o prawie $80 \%$ mniejsza w przypadku mieszkających na wsi, o ok. $60 \%$ niższa w przypadku małych miast i o ok. $55 \%$ niższa w przypadku mieszkańców miast średniej wielkości;

- samoocena stanu zdrowia - szansa dłuższej aktywności zawodowej jest prawie trzykrotnie większa w przypadku przeciętnej oceny niż w przypadku oceniających swe zdrowie źle; znacznie większa różnica względem osób w złej kondycji zdrowotnej (ponad 8-krotna) ma miejsce w przypadku dobrze oceniających swoje zdrowie;

- poziom wykształcenia - w odniesieniu do osób z wykształceniem wyższym prawdopodobieństwo dłuższej aktywności zawodowej (w ujęciu deklaratywnym) jest o ok. $87 \%$ niższe w przypadku tych najsłabiej wykształconych, o ok. $65 \%$ niższe dla mających wykształcenie zasadnicze zawodowe, zaś dla osób z wykształceniem średnim jest o ok. $49 \%$ niższe;

- sprawowanie opieki - osoby mające obowiązki opiekuńcze mają o ok. 30\% niższą szansę na dłuższą aktywność zawodową niż niesprawujące opieki;

- obecna sytuacja zawodowa - szansa dłuższej aktywności zawodowej jest ok. dwukrotnie wyższa w przypadku pracujących na własny rachunek w porównaniu z zatrudnionymi na podstawie umowy o pracę na czas nieokreślony; w przypadku innych form zatrudnienia szansa ta jest niższa w stosunku do grupy odniesienia, a w przypadku rolników wyższa, jednak nie zdiagnozowano tu istotnych różnic;

- podejmowanie aktywności edukacyjnej - szansa dłuższej aktywności zawodowej jest ok. 1,5-krotnie wyższa w przypadku podejmujących taką aktywność.

Spore znaczenie mają warunki pracy, jednak w ich przypadku $p$ jest nieco wyższe niż 0,1 , trudno więc $\mathrm{w}$ takim przypadku o uogólnienie na całą populację.

Należy zwrócić uwagę, że wśród istotnych czynników nie ma takich zmiennych, jak wiek czy staż pracy, mobilność zawodowa mierzona liczbą pracodawców (ogółem i po 45. roku życia) czy podejmowaniem działalności gospodarczej, zaangażowanie w działalność społeczną ${ }^{5}$. Nie znaczy to oczywiście, że nie mają one znaczenia na etapie podejmowania indywidualnych decyzji o momencie przejścia na emeryturę (wcześniejsza analiza wykazała zresztą występowanie takich związków), niemniej jednak na tle pozostałych czynników ich rola jest drugoplanowa.

5 Ponieważ badanie dotyczyło wszystkich pracujących, a nie tylko zatrudnionych, w modelu nie uwzględniono pełnego zestawu analizowanych wcześniej czynników (niektóre z nich badane były tylko dla grupy zatrudnionych). 
Wydtużenie aktywności zawodowej czy przejście na emeryturę?...

Uzyskane dla Polski wyniki są więc zbieżne z analogicznymi badaniami prowadzonymi w innych krajach UE.

Omówione powyżej czynniki wydłużania aktywności zawodowej można określić jako obiektywne, są bowiem wypadkową cech społeczno-ekonomicznych i warunków życia osobistego i zawodowego. Na podstawie wyników Diagnozy można również wskazać subiektywne przyczyny takiego a nie innego podejścia do własnej aktywności zawodowej w końcowej fazie kariery zawodowej. Spontanicznie wskazując powody planowanej dezaktywizacji zawodowej, pracujący wskazywali najczęściej na zmęczenie pracą (ok. 37\%), w następnej kolejności zaś - na czynniki wynikające $\mathrm{z}$ biologicznych cech procesu starzenia, a konkretnie z obniżenia kondycji zdrowotnej - co trzecia osoba wskazała na zły stan zdrowia (ok. 34\%), a ok. $20 \%$ na zbyt duże obciążenie fizyczne lub psychiczne w aktualnym miejscu pracy. Powyższe okoliczności dają duże pole dla instrumentów zarządzania wiekiem - przesunięcie na inne stanowisko, profilaktyka prozdrowotna to przykłady działań, które mogłyby się przyczynić do utrzymania w zatrudnieniu obecnie pracujących w wieku 45+. Duże znaczenie powinny też odgrywać rozwiązania pozwalające na utrzymanie równowagi praca-życie - 14\% osób postrzega emeryturę jako czas, który mogłaby w większym stopniu poświęcać rodzinie. Dla $8 \%$ obecnie pracujących w wieku 45-69 lat emerytura kojarzy się ze stabilnością finansową, pewnym źródłem dochodu, a obecna płaca nie stanowi wystarczającego motywatora pozostania w zatrudnieniu. Dla części tej grupy przejście na emeryturę postrzegane jest także jako naturalny etap ich życia i planują przejść na emeryturę, gdyż osiągnęły odpowiedni wiek, wypracowały lata pracy. Wśród wymienianych powodów dezaktywizacji zawodowej znalazło się również przekonanie o osiągnięciu maksimum możliwości zawodowych, chęć realizacji własnych marzeń.

Osoby, które nie myślą o jak najszybszym odejściu na emeryturę, jako powód podają przede wszystkim zadowolenie z pracy, zawodowe spełnienie. Przez osoby chcące dalej pracować, praca traktowana jest jako wartość sama w sobie - dzięki niej czują się dowartościowane, praca pozwala im zachować lepszą kondycję fizyczną i psychiczną, zaspokaja potrzeby społeczne, zapewniając kontakt z ludźmi, daje możliwość rozwoju. Dla co trzeciej osoby z grupy nieplanujących szybkiego przejścia na emeryturę przyczyna jest dużo bardziej prozaiczna - praca jest przecież źródłem dochodów, a emerytura jest zbyt niska.

\section{W JAKI SPOSÓB WSPIERAĆ AKTYWNOŚĆ ZAWODOWA W FAZIE PÓŹNEJ DOROSŁOŚCI?}

Podejście do kwestii wydłużania aktywności zawodowej może być dwojakie. Po pierwsze, ogranicza się dostęp do alternatywnych wobec dochodów z pracy źródeł utrzymania osób starszych, po drugie - zwraca się dodatkowo uwagę na otoczenie środowiska pracy. W podejściu pierwszym akcentuje się potrzebę podnoszenia usta- 
wowego wieku emerytalnego, ograniczania uprawnień do wcześniejszych emerytur i innych świadczeń z ubezpieczeń społecznych. W podejściu drugim, z kolei, nacisk kładzie się na działania na rzecz poprawy funkcjonowania otoczenia edukacyjnego, zdrowotnego, społecznego lub infrastruktury rynku pracy (Kryńska 2006). W Polsce wdrożono już rozwiązania wpisujące się w pierwsze z podejść. Zgodnie z obowiązującym od 1 stycznia 2013 r. prawem (Ustawa 2012), wiek emerytalny kobiet i mężczyzn podnoszony będzie sukcesywnie do 67 lat (w wieku 67 lat nabędą uprawnienia do emerytury kobiety urodzone po 30 września 1973 r. oraz mężczyźni urodzeni po 30 września 1953 r.). Ograniczone zostały również uprawnienia do wcześniejszych emerytur (w wyniku zmiany Ustawy z dnia 17 grudnia 1998 r. o emeryturach $i$ rentach z Funduszu Ubezpieczeń Społecznych - nowela z dnia 28 marca 2008 r. oraz wejścia w życie Ustawy z dnia 19 grudnia 2008 r. o emeryturach pomostowych, prowadzących do ograniczenia liczby uprawnionych do wcześniejszego przejścia na emeryturę z tytułu pracy w szczególnych warunkach lub o szczególnym charakterze - por. Włodarczyk, Paluszkiewicz 2011: 41). Jak podkreślano wcześniej, zagadnienia te nie są przedmiotem niniejszej pracy.

$\mathrm{Z}$ pomocą środków z Europejskiego Funduszu Społecznego realizowane są $\mathrm{z}$ kolei $\mathrm{w}$ Polsce - podobnie jak w innych krajach UE - działania wpisujące się $\mathrm{w}$ drugie $\mathrm{z}$ przedstawionych wyżej podejść, tj. związane $\mathrm{z}$ otoczeniem środowiska pracy. Realizowane w Polsce działania ukierunkowane na wydłużenie aktywności zawodowej i ogólnie na lepsze wykorzystanie potencjału osób w wieku $50+$ na rynku pracy reguluje wdrażany od 2008 r. rządowy program Solidarność pokoleń. Działania dla zwiększenia aktywności zawodowej osób w wieku 50+, zaktualizowany w 2013 r. Program ten wpisuje się w realizację celów i działań określonych w strategii horyzontalnej Polska 2030. Trzecia fala nowoczesności. Dlugookresowa Strategia Rozwoju Kraju z 11 stycznia 2013 r., Strategii Rozwoju Kraju 2020 z 25 września 2012 r. oraz sektorowej Strategii Rozwoju Kapitału Ludzkiego 2020 z 18 czerwca 2013 r. i dokumentu Perspektywa uczenia się przez cate życie z 10 września 2013 r. (por. Program Solidarność Pokoleń 2013). Program przewiduje realizację następujących celów szczegółowych: (1) dostosowanie kompetencji osób $45+$ do potrzeb rynku pracy oraz podniesienie ich kwalifikacji, (2) rozwój kultury organizacji i środowiska pracy bardziej przyjaznych pracownikom w wieku 50+, (3) zwiększenie skuteczności i efektywności działań promujących zatrudnienie i aktywność zawodową, (4) wspieranie idei aktywnego i zdrowego starzenia się, (5) rozwój współpracy na rzecz wzrostu zatrudnienia osób 50+, (6) transfery społeczne wspierające aktywność zawodową osób $\mathrm{w}$ wieku przedemerytalnym.

Polskie działania w obszarze polityki społecznej, w tym w szczególności polityka rynku pracy wobec starszych jego uczestników, wpisuje się w wytyczne formułowane na poziomie unijnym. Poczynając od komunikatu z 1999 r. pt. Towards a Europe for All Ages (European Commission 1999) i dokumentu pt. Draft Joint Employment Report (European Commission 2001), państwa członkowskie intensyfikują działania w zakresie aktywnego starzenia się poprzez kreowanie narzędzi 
umożliwiających podtrzymywanie kompetencji starszych pracowników, wdrażanie elastycznych warunków pracy oraz rozwój wiedzy pracodawców na temat potencjału starszych pracowników. Należy zapewnić starszym pracownikom należyty dostęp do edukacji i szkoleń, a także zrewidować system podatkowy oraz zabezpieczenie społeczne w taki sposób, aby ograniczyć utrudnienia i rozwijać zachęty do pozostawania aktywnym na rynku pracy w starszym wieku. Politykę aktywnego starzenia się oparto przy tym na zachęcaniu starszych pracowników do jak najdłuższego pozostawania na rynku pracy, ograniczaniu determinant niskiej aktywności zawodowej osób w wieku przedemerytalnym oraz na rozwijaniu kształcenia ustawicznego (idea lifelong learning) (Wysokińska 2013: 47-48; European Commission 2012), a także na upowszechnianiu międzypokoleniowego transferu wiedzy (Urbaniak, Wiktorowicz 2014). Działania prowadzone w Polsce ukierunkowane są na realizację powyższych postulatów (przy czym ostatni z nich nie cieszy się jeszcze zbyt dużym zainteresowaniem). Istotne jest również proaktywne, prewencyjne podejście do aktywności zawodowej poprzez lepsze zarządzanie ludźmi w każdej fazie ich życia zawodowego. Służą temu wpisujące się w koncepcję work ability (zdolności do pracy) działania z obszaru zarządzania wiekiem (Ilmarinen 2005: 132-133) ${ }^{6}$. Model work ability opiera się na równowadze między stroną podażową i popytową rynku pracy. Od strony pracowników nacisk kładziony jest na zdrowie, edukację, kompetencje, wartości i postawy, od strony pracodawców zaś - na adekwatny do potrzeb starzejących się zasobów pracy, rozwój środowisk pracy, aktualne treści pracy, wymagania, organizację pracy, zarządzanie. Jakość pracy powinna ulec poprawie poprzez utrzymanie lepszego stanu zdrowia fizycznego i psychicznego, równowagę praca-życie, ulepszenia w środowisku pracy oraz - na poziomie jednostkowym - poprawę jakości życia i produktywności pracowników. Koncepcja ta, od 30 lat z powodzeniem wcielana w życie w Finlandii, stanowi ważny element polityki aktywnego starzenia się nie tylko w krajach europejskich, powoli zaznacza się również w praktyce polskich przedsiębiorstw.

Prowadzona w Polsce polityka była i jest spójna także z założeniami Europejskiej Strategii Zatrudnienia oraz strategii UE - zarówno Strategii Lizbońskiej, jak i obecnie realizowanej strategii Europa 2020. Działania publiczne podejmowane na terenie Wspólnoty skupiają się na wbudowywaniu w system prawnoinstytucjonalny bodźców zachęcających osoby na przedpolu starości do dłuższej aktywności zawodowej, umożliwiających ją lub wręcz do niej zmuszających (szerzej na te temat - zob. np. Kryńska, Szukalski 2013). Ważne jest jednak również oddziaływanie na jednostkowe decyzje osób w wieku okołoemerytalnym, co wyraźnie wynika z omówionego uprzednio zróżnicowania podejścia do własnej aktywności zawodowej osób w wieku $50+$.

6 Zasadniczym elementem modelu jest WAI - Work Ability Index, który w prosty sposób mierzy zdolność do pracy. Indeks ten z powodzeniem wykorzystywany był również w polskich warunkach (por. np. Kaleta, Makowiec-Dąbrowska, Jegier 2006; Bugajska, Makowiec-Dąbrowska, Wągrowska-Koski 2010, Bortkiewicz, Makowiec-Dąbrowska 2008). 
Kierunki wsparcia aktywności zawodowej starszego pokolenia Polaków są w ostatnich latach przedmiotem licznych badań i analiz, a wypracowane rekomendacje odnoszone są zarówno do poziomu makro-, mezo-, jak i mikroekonomicznego (por. np. Błędowski, Szuwarzyński 2009; Bukowski 2010; Dubas i in. 2008; Giza-Poleszczuk i in. 2008, Kołodziejczyk-Olczak 2010; Kotowska-Wóycicka 2008; Krajewski 2010; Kryńska i in. (red.) 2013; Kryńska, Szukalski 2013; Krzyszkowski 2010; Liwiński, Sztanderska 2010; Mossakowska i in. 2012; Perek-Białas i in. 2011; Sadowska-Snarska (red.) 2011; Schimanek i in. 2011; Sobocka-Szczapa (red.) 2011; Szatur-Jaworska, Rysz-Kowalska 2007; Szarota 2010; Szmidt (red.) 2012; Szukalski 2008, 2012; Urbaniak 2007, 2011; Uścińska 2011; Wiktorowicz 2010; Wiśniewski 2009). Z uwagi na ograniczone ramy pracy, pominięty został przegląd postulatów zgłaszanych w wymienionych opracowaniach, przy czym należy podkreślić, że wpisują się one w ramy wyznaczone przez Komisję Europejską. W sposób bardziej szczegółowy, odwołując się do wyników Diagnozy, zaprezentowane zostaną w tym miejscu opinie samych zainteresowanych w tym zakresie.

Jakie czynniki mogą skłonić osoby w wieku $45+$ do kontynuowania pracy zawodowej? Sumarycznie (niezależnie od pozycji w rankingu), największe znaczenie pracujący w wieku $45+$ przypisywali: podniesieniu wynagrodzenia (50\% wskazań), zmniejszeniu liczby godzin pracy ( $24 \%$ wskazań), przesunięciu na stanowisko wymagające mniejszego wysiłku fizycznego ( $23 \%$ wskazań), elastycznym godzinom pracy (20\% wskazań), dogodniejszej organizacji pracy (15\% wskazań), przesunięciu do pracy mniej stresującej (14\% wskazań) czy na stanowisko mniej obciążające umysłowo (7\%), dostosowanie stanowiska pracy do potrzeb starszych pracowników (12\% wskazań), w tym jego specjalne wyposażenie (9\%), możliwość wykonywania (czasami) pracy w domu ( $9 \%$ wskazań). W większości są to rozwiązania dotyczące uelastycznienia form zatrudnienia lub zmiany organizacji pracy zgodnie z potrzebami starszych pracowników, a więc są to „klasyczne” instrumenty zarządzania wiekiem w organizacji. Wśród innych powodów deklaratywnego kontynuowania zatrudnienia wymieniano także mniej szkodliwie warunki pracy, przydzielenie specjalnych zadań, dostosowanych do kwalifikacji pracownika, zmiany formy umowy na umowę o pracę na czas nieokreślony. Pojedyncze osoby wskazywały także, że chcą przejść na emeryturę i równolegle dorabiać. $Z$ drugiej strony, co piąty obecnie pracujący w wieku 45-69 lat uważa, że nic nie skłoniłoby go do kontynuowania pracy zawodowej, przy czym, o ile w przypadku mężczyzn przekonanie to jest słabsze raczej po 50. niż przed 50. rokiem życia, to wśród kobiet przed przekroczeniem tej granicy wieku.

Płeć różnicuje kolejność wskazywanych motywatorów do wydłużenia aktywności zawodowej (tablica 3), niemniej jednak zdecydowanie najczęściej wymieniane są trzy instrumenty zarządzania zasobami ludzkimi, z których dwa zaliczane są do obszarów zarządzania wiekiem. Wynagrodzenia są bowiem bezpośrednim motywatorem aktywności zawodowej neutralnym ze względu na wiek. W świetle danych GUS, wynagrodzenia osób w wieku 50+ są i tak stosunkowo wysokie w porównaniu 
z osobami młodszymi - sięgają średnio 3670 zł brutto (według danych za $2010 \mathrm{r}$. - GUS 2012a) wobec średniej krajowej na poziomie 3225 zł (GUS 2012b). Co więcej, średnia ta rośnie z wiekiem, co potwierdzają zarówno dane GUS (dla grupy 65+ średnia przekracza 5200 zł brutto wobec ok. 3500 zł brutto dla osób w wieku 50-54 lata), jak i Diagnozy (dla grupy 50-54 lata średni dochód netto sięga ok. 1180 zł, podczas gdy dla pracujących w wieku $65+$ jest to ok. $2360 \mathrm{zl}$ ). Można zatem powiedzieć, że w polskich realiach postulat ten (wyższe wynagrodzenie zgodnie z zasadą senioralną) jest rzeczywiście realizowany. Z drugiej strony, warto zauważyć, że po przekroczeniu granicy wieku emerytalnego na pracę decydują się zwłaszcza osoby na stanowiskach specjalistycznych i kierowniczych, których wiedza stanowi na tyle dużą wartość dla organizacji, że gotowa jest ponosić wyższe koszty. Charakter pracy tych ,wyselekcjonowanych” osób powoduje, że średnie wynagrodzenie jest w tej właśnie grupie wieku wyraźnie wyższe niż w grupach młodszych. Biorąc pod uwagę całą populację pracujących w wieku 45-69 lat należy zauważyć, że osoby o niższych kwalifikacjach nie mogą liczyć na wysokie zarobki (dla osób z wykształceniem podstawowym średni dochód to ok. 1600 zł netto, a więc o ok. $1000 \mathrm{zł}$ mniej niż dla osób z wykształceniem wyższym). Nie dziwi więc, że osoby najsłabiej wykształcone jako uzasadnienie podejścia do wydłużania swojego życia zawodowego podawały wyłącznie czynniki ekonomiczne, podczas gdy osoby z wykształceniem wyższym lub średnim - przede wszystkim zadowolenie z pracy, zawodowe spełnianie się.

Tablica 3. Najważniejsze instrumenty, których wdrożenie skłoniłoby pracujących w wieku $45+$ do wydłużenia okresu zatrudnienia według płci

Table 3. Main policy instruments which could extend the working lives of workers aged 45+, by sex

\begin{tabular}{|c|c|c|}
\hline $\begin{array}{l}\text { Czynnik } \\
\text { Factor }\end{array}$ & $\begin{array}{l}\text { Kobiety } \\
(\text { Women })\end{array}$ & $\begin{array}{l}\text { Mężczyźni } \\
\text { (Men) }\end{array}$ \\
\hline 1 & $\begin{array}{l}\text { - wyższe wynagrodzenie }(31 \%) \\
\text { - przesunięcie na stanowisko wymagające } \\
\text { mniejszego wysiłku fizycznego }(13 \%) \\
\text { - zmniejszenie liczby godzin pracy }(9 \%)\end{array}$ & $\begin{array}{l}\text { - wyższe wynagrodzenie }(25 \%) \\
\text { - przesunięcie na stanowisko wymagające } \\
\text { mniejszego wysiłu fizycznego }(14 \%) \\
\text { - zmniejszenie liczby godzin pracy }(10 \%)\end{array}$ \\
\hline 2 & $\begin{array}{l}\text { - wyższe wynagrodzenie }(15 \%) \\
\text { - elastyczne godziny pracy }(9 \%) \\
\text { - zmniejszenie liczby godzin pracy }(9 \%)\end{array}$ & $\begin{array}{l}\text { - wyższe wynagrodzenie }(13 \%) \\
\text { - zmniejszenie liczby godzin pracy }(9 \%)\end{array}$ \\
\hline 3 & $\begin{array}{l}\text { - wyższe wynagrodzenie }(10 \%) \\
\text { - zmniejszenie liczby godzin pracy }(5 \%) \\
\text { - elastyczne godziny pracy }(5 \%) \\
\text { - przystosowanie stanowiska pracy do } \\
\text { ograniczonych możliwości starszego } \\
\text { pracownika }(5 \%)\end{array}$ & $\begin{array}{l}\text { - wyższe wynagrodzenie }(7 \%) \\
\text { - zmniejszenie liczby godzin pracy }(6 \%) \\
\text { - elastyczne godziny pracy }(4 \%) \\
\text { - przystosowanie stanowiska pracy do } \\
\text { ograniczonych możliwości starszego } \\
\text { pracownika }(4 \%) \\
\text { - dogodniejsza organizacja pracy }(4 \%)\end{array}$ \\
\hline
\end{tabular}

Źródło: Wiktorowicz 2012.

Source: Wiktorowicz 2012. 
Na oczekiwany wzrost wynagrodzenia wskazują w badaniu osób w wieku 45+ głównie pracownicy najemni (29\%), a wśród nich nieznacznie częściej kierownicy (35\%) niż specjaliści (31\%) czy zajmujący stanowiska robotnicze (30\%). Pracujących na własny rachunek także najbardziej przekonałyby wyższe dochody, zaś rolników - praca mniej obciążająca fizycznie. Robotnicy niewykwalifikowani, wykonujący proste prace, oczekują przede wszystkim przesunięcia na stanowisko niewymagające wysokiego obciążenia fizycznego - dotyczy to zwłaszcza kobiet. Podobną opinię wyrażają kobiety i mężczyźni pracujący we własnym gospodarstwie rolnym. W przypadku pozostałych grup na pierwszym miejscu najczęściej stawiano wynagrodzenie (tablica 4).

Tablica 4. Najważniejsze (wskazane na pierwszym miejscu) instrumenty, których wdrożenie skłoniłoby pracujących w wieku $45+$ do kontynuacji zatrudnienia według grup zawodowych i płci*

Table 4. The main (indicated as the most important) policy instruments which could stimulate workers aged $45+$ to extending their working lives, by occupation and sex*

\begin{tabular}{|c|c|c|}
\hline $\begin{array}{l}\text { Grupa } \\
\text { Group }\end{array}$ & $\begin{array}{l}\text { Kobiety }(\mathrm{K}) \\
\text { Women }(K)\end{array}$ & $\begin{array}{l}\text { Mężczyźni (M) } \\
\text { Men (M) }\end{array}$ \\
\hline $\begin{array}{l}\text { Robotnicy } \\
\text { niewykwalifiko- } \\
\text { wani } \\
\text { Unskilled workers } \\
\left(n_{K}=46, n_{M}=31\right)\end{array}$ & $\begin{array}{l}\text { - przesunięcie na stanowisko } \\
\text { wymagące mniejszego wysiłku } \\
\text { fizycznego }(41 \%) \\
\text { - wyższe wynagrodzenie }(37 \%) \\
\text { - elastyczne godziny pracy }(9 \%)\end{array}$ & $\begin{aligned} \text { - wyższe wynagrodzenie } \\
\\
(35 \%) \\
- \text { zmniejszenie liczby godzin pracy } \\
\quad(13 \%) \\
\text { - } \\
\text { elastyczne godziny pracy } \\
(13 \%) \\
- \text { przesunięcie na stanowisko mniej } \\
\text { obciążające umysłowo }(13 \%) \\
- \text { przesunięcie na stanowisko } \\
\text { wymagaące mniejszego wysiłku } \\
\text { fizycznego }(10 \%)\end{aligned}$ \\
\hline $\begin{array}{l}\text { Robotnicy } \\
\text { wykwalifikowani } \\
\text { Skilled workers } \\
\left(n_{K}=157, n_{M}=326\right)\end{array}$ & $\begin{array}{l}\text { - wyższe wynagrodzenie }(43 \%) \\
\text { - przesunięcie na stanowisko } \\
\text { wymagąace mniejszego wysiłku } \\
\text { fizycznego }(24 \%) \\
\text { - zmniejszenie liczby godzin pracy } \\
(9 \%)\end{array}$ & $\begin{array}{l}\text { - wyższe wynagrodzenie } \\
(33 \%) \\
\text { - przesunięcie na stanowisko } \\
\text { wymagające mniejszego wysiłku } \\
\text { fizycznego }(21 \%) \\
\text { - zmniejszenie liczby godzin pracy } \\
(12 \%) \\
\text { - elastyczne godziny pracy }(8 \%)\end{array}$ \\
\hline $\begin{array}{l}\text { Specjaliści } \\
\text { Specialists } \\
\left(n_{K}=161, n_{M}=107\right)\end{array}$ & $\begin{array}{l}\text { - wyższe wynagrodzenie }(38 \%) \\
\text { - zmniejszenie liczby godzin pracy } \\
(12 \%) \\
\text { - przesunięcie do pracy mniej } \\
\text { stresującej }(10 \%) \\
\text { - elastyczne godziny pracy }(9 \%)\end{array}$ & $\begin{aligned} \text { - wyższe wynagrodzenie } \\
\\
(29 \%) \\
\text { - przesunięcie do pracy mniej } \\
\text { stresującej (18\%) } \\
\text { - przesunięcie na stanowisko } \\
\text { wymagające mniejszego wysiłku } \\
\text { fizycznego (13\%) } \\
\text { - zmniejszenie liczby godzin pracy } \\
\quad(11 \%)\end{aligned}$ \\
\hline
\end{tabular}


Wydtużenie aktywności zawodowej czy przejście na emeryturę?...

\begin{tabular}{|c|c|c|}
\hline $\begin{array}{l}\text { Grupa } \\
\text { Group }\end{array}$ & $\begin{array}{l}\text { Kobiety }(\mathrm{K}) \\
\text { Women }(K)\end{array}$ & $\begin{array}{c}\text { Mężczyźni (M) } \\
\text { Men (M) }\end{array}$ \\
\hline $\begin{array}{l}\text { Pomocnicza kadra } \\
\text { administracyjna } \\
\text { Auxiliary } \\
\text { administrative } \\
\text { staff } \\
\left(n_{K}=79, n_{M}=26\right)\end{array}$ & $\begin{array}{l}\text { - wyższe wynagrodzenie (34\%) } \\
\text { - zmniejszenie liczby godzin pracy } \\
(19 \%) \\
\text { - przesunięcie do pracy mniej } \\
\text { stresującej }(10 \%) \\
\text { - elastyczne godziny pracy }(9 \%) \\
\text { - możliwość wykonywania czasami } \\
\text { pracy w domu (9\%) } \\
\text { - dogodniejsza organizacja pracy } \\
(8 \%)\end{array}$ & $\begin{array}{l}\text { - wyższe wynagrodzenie }(31 \%) \\
\text { - zmniejszenie liczby godzin pracy } \\
\text { (19\%) } \\
\text { - przesunięcie do pracy mniej } \\
\text { stresującej }(15 \%) \\
\text { - elastyczne godziny pracy }(12 \%) \\
\text { - możliwość wykonywania pracy } \\
\text { czasami w domu }(8 \%) \\
\text { - przystosowanie stanowiska pracy } \\
\text { do ograniczonych możliwości } \\
\text { starszego pracownika }(8 \%)\end{array}$ \\
\hline $\begin{array}{l}\text { Kierownicy } \\
\text { Managers } \\
\left(n_{K}=32, N_{M}=30\right)\end{array}$ & $\begin{array}{l}\text { - wyższe wynagrodzenie }(41 \%) \\
\text { - elastyczne godziny pracy }(19 \%) \\
\text { - przesunięcie do pracy mniej } \\
\text { stresującej ( } 16 \%) \\
\text { - możliwość wykonywania pracy } \\
\text { czasami w domu }(13 \%)\end{array}$ & $\begin{array}{l}\text { - wyższe wynagrodzenie }(43 \%) \\
\text { - dogodniejsza organizacja pracy } \\
\quad(10 \%) \\
\text { - przesunięcie do pracy mniej } \\
\text { stresującej }(10 \%)\end{array}$ \\
\hline $\begin{array}{l}\text { Pracujący na } \\
\text { własny rachunek } \\
\text { Self-employed } \\
\left(n_{K}=36, n_{M}=87\right)\end{array}$ & $\begin{array}{l}\text { - wyższe wynagrodzenie }(33 \%) \\
\text { - elastyczne godziny pracy }(19 \%) \\
\text { - zmniejszenie liczby godzin pracy } \\
\text { (17\%) } \\
\text { - przystosowanie stanowiska pracy } \\
\text { do ograniczonych możliwości } \\
\text { starszego pracownika }(8 \%)\end{array}$ & $\begin{array}{l}\text { - wyższe wynagrodzenie }(24 \%) \\
\text { - zmniejszenie liczby godzin pracy } \\
(20 \%) \\
\text { - przesunięcie na stanowisko } \\
\text { wymagające mniejszego wysiłku } \\
\text { fizycznego }(17 \%) \\
\text { - elastyczne godziny pracy }(13 \%) \\
\text { - dogodniejsza organizacja pracy } \\
(9 \%)\end{array}$ \\
\hline $\begin{array}{l}\text { Rolnicy } \\
\text { Farmers } \\
\left(n_{K}=40, n_{M}=51\right)\end{array}$ & $\begin{array}{l}\text { - przesunięcie na stanowisko } \\
\text { wymająąe mniejszego wysiłku } \\
\text { fizycznego }(28 \%) \\
\text { - wyższe wynagrodzenie }(28 \%) \\
\text { - zmniejszenie liczby godzin pracy } \\
\quad(13 \%) \\
\text { - elastyczne godziny pracy }(13 \%)\end{array}$ & $\begin{array}{l}\text { - przesunięcie na stanowisko } \\
\text { wymagające mniejszego wysiłku } \\
\text { fizycznego }(29 \%) \\
\text { - wyższe wynagrodzenie }(22 \%) \\
\text { - przystosowanie stanowiska pracy } \\
\text { do ograniczonych możliwości } \\
\text { starszego pracownika (10\%) } \\
\text { - zmniejszenie liczby godzin pracy } \\
(10 \%) \\
\text { - dogodniejsza organizacja pracy } \\
(8 \%)\end{array}$ \\
\hline
\end{tabular}

* Odsetki wyznaczono po pominięciu odp. „nic nie skłoniłoby mnie do pozostania w zatrudnieniu”. Niektóre podpróby są na tyle małe, że zaprezentowane odsetki mogą pełnić jedynie rolę poglądową (liczebności każdej z nich $-N$ - podano w tablicy 1 ). W tablicy pominięto te warianty, dla których odsetki są niskie (poniżej 8\%).

* The calculated percentages exclude the answer "nothing would make me continue working". Some of the sub-samples are so small that the presented proportions are only used for illustration (the respective sample sizes $-n_{K}$ for women and $n_{M}$ for men - are given in the table). The table omits variants with low proportions (less than $8 \%$ ).

Źródło: jak w tablicy 1.

Source: as in table 1. 
Stanowiska specjalistyczne czy kierownicze wyraźnie częściej związane są ze stresem, co powoduje, że osoby w wieku 45+ wolałyby zostać przesunięte do pracy mniej narażonej na ten czynnik - jest to warunek stawiany na pierwszym miejscu przez znaczną część zatrudnionych z tych grup (odsetek wskazań plasuje go w grupie trzech najważniejszych powodów). Inne ważne w przypadku tej grupy czynniki pozostania w zatrudnieniu to zmniejszenie liczby godzin pracy (w mniejszym stopniu dotyczy to kierowników), elastyczne godziny pracy czy jej dogodniejsze warunki. Podejście rolników - z uwagi na charakter pracy - jest zbliżone do podejścia robotników niewykwalifikowanych, zaś pracujących na własny rachunek - do specjalistów czy pomocniczej kadry kierowniczej. Rozpatrując potencjalne ścieżki wsparcia aktywności zawodowej osób w wieku 45+, należy - podobnie jak to jest postulowane w Wielkiej Brytanii (Weyman i in. 2012) - wziąć pod uwagę zróżnicowane podejście poszczególnych grup zawodowych (w szerszym czy węższym rozumieniu).

Omawiane opinie powiązane są - co zrozumiałe - również z warunkami pracy. Dla osób ciężko pracujących fizycznie wyższe wynagrodzenie jest niemal tak samo ważne jak przesunięcie na stanowisko mniej obciążające fizycznie (ponad 20\% osób postawiło drugi z wymienionych czynników na pierwszym miejscu). Z kolei dla osób, których praca nie wymaga wysiłku fizycznego, najważniejsze - obok wynagrodzenia - jest zmniejszenie liczby godzin pracy (14\%) oraz przesunięcie do pracy mniej stresującej (9\%).

\section{WNIOSKI KOŃCOWE}

Obserwowane tendencje demograficzne, ekonomiczne i społeczne wymuszają wydłużanie okresu aktywności zawodowej Polaków, podobne prawidłowości obserwuje się w większości krajów UE. Decyzja o dłuższej aktywności może być przy tym wymuszona (poprzez rozwiązania systemu emerytalnego), można ją też stymulować poprzez odpowiednio prowadzoną politykę społeczną, w tym zwłaszcza politykę rynku pracy. Jak pokazują doświadczenia europejskie, podejście do tej kwestii nie może być fragmentaryczne, jedynie holistyczne, wpisujące się w koncepcję cyklu życia ujęcie problematyki aktywnego starzenia (także w tym wąskim wymiarze aktywności zawodowej) jest gwarantem sukcesu i w tym kierunku powinny ewoluować również polskie rozwiązania.

W świetle przytoczonych wyników badań, powodem planowanego szybkiego odejścia na emeryturę są przede wszystkim warunki wynikające z kondycji fizycznej i psychicznej, ogólnego zmęczenia pracą i życiem, zaś jako powód pozostania w zatrudnieniu - głównie czynniki związane z samorealizacją. Widać przy tym wyraźne zróżnicowanie opinii osób słabiej i lepiej wykształconych, ale też „dużych” grup zawodowych (zatrudnieni, pracujący na własny rachunek, rolnicy), mniejsze są natomiast różnice między osobami z różnych grup wieku oraz kobietami i męż- 
czyznami. O możliwie szybkiej dezaktywizacji zawodowej myślą przede wszystkim osoby o niższym poziomie wykształcenia, których umiejętności są zdezaktualizowane (problem stanowią zwłaszcza niedostateczne umiejętności informatyczne), niebędące specjalistami w swojej dziedzinie. Niskie kompetencje, szczególnie $\mathrm{w}$ zestawieniu $\mathrm{z}$ wiekiem okołoemerytalnym, rzutują na znaczne trudności w znalezieniu nowej pracy w sytuacji ewentualnego bezrobocia. Możliwie wczesna emerytura traktowana jest $\mathrm{w}$ takiej sytuacji jako bufor bezpieczeństwa. Zgoła odmienne podejście mają osoby o wyższych kompetencjach, zajmujący stanowiska specjalistyczne, często kluczowe dla organizacji, których pozycja w miejscu pracy (ale też na otwartym rynku pracy) jest tym samym wysoka. Główną barierą może być w ich przypadku stan zdrowia (w tym zwłaszcza wypalenie zawodowe). Oczywiście jest to uproszczony obraz podejścia do własnej aktywności zawodowej osób w wieku $50+$, niemniej jednak przeprowadzone analizy (te i innych autorów) pozwalają na takie generalizowanie oceny.

Dalszej aktywności zawodowej obecnie pracujących w wieku 45-69 lat sprzyjać może i powinno, m.in. wdrożenie różnych instrumentów zarządzania wiekiem (rozwiązania z tego obszaru były najczęściej wskazywane przez samych zainteresowanych). Ponownie wyraźnie zaznacza się potrzeba różnicowania instrumentów wsparcia kierowanych do różnych grup zawodowych - co zrozumiałe, inne działania będą skuteczne w przypadku osób, których praca wiąże się z większym wysiłkiem fizycznym (robotnicy niewykwalifikowani, rolnicy), inne w przypadku osób zajmujących stanowiska kierownicze, specjalistyczne czy pracujących na własny rachunek. O ile w przypadku pierwszej z grup ważne jest przede wszystkim wdrażanie zmian $\mathrm{w}$ organizacji pracy, o tyle $\mathrm{w}$ odniesieniu do drugiej grupy ważniejsze są elastyczne formy zatrudnienia. Postulat ten uwzględniają założenia wspomnianego we wprowadzeniu programu „Solidarność pokoleń”. Istotne jest, aby projektowanie szczegółowych rozwiązań, m.in. realizowanych w ramach środków Europejskiego Funduszu Społecznego w kolejnej perspektywie finansowej, również uwzględniały tę dywersyfikację podejścia do własnej aktywności zawodowej osób z tej generacji.

\section{LITERATURA}

Błędowski P., A. Szuwarzyński, 2009, Aktywizacja zawodowa osób w wieku 50+ - szanse i ograniczenia, PBS DGA, Sopot.

Bortkiewicz A., T. Makowiec-Dąbrowska, 2008, Wiek a zdolność do pracy, [w:] J. Kleer (red.), Konsekwencje ekonomiczne i społeczne starzenia się spoleczeństwa, Polska Akademia Nauk, Komitet Prognoz «Polska 2000 Plus» Warszawa, s. 138-167.

Bugajska J., T. Makowiec-Dąbrowska, E. Wągrowska-Koski, 2010, Zarządzanie wiekiem w przedsiębiorstwach jako element ochrony zdrowia starszych pracowników, Medycyna Pracy, 61(1), s. $55-63$.

Bukowski M. (red.), 2010, Zatrudnienie w Polsce 2008. Praca w cyklu życia, Centrum Rozwoju Zasobów Ludzkich, Warszawa. 
Chłon-Domińczak A., 2009, Retirement Behaviour in Poland and the Potential Impact of Pension System Changes, ENEPRI Research Report No 63, AIM project, http://aei.pitt.edu/10745/ (data dostępu: 15.02.2014).

Contreras N., E. Martellucci, A.-E. Thum, 2013, Extending Working Life in Belgium, "CEPS Working Document", nr 386.

Czapiński J., T. Panek (red.), 2013, Diagnoza Spoleczna 2013. Warunki i jakość życia Polaków, Centrum Rozwoju Zasobów Ludzkich, Warszawa.

Czarnik S., K. Turek, 2014, Aktywność zawodowa i wyksztatcenie Polaków. Edukacja a rynek pracy - tom II, PARP, Warszawa.

Determinanty dezaktywizacji zawodowej osób po 45 roku życia. Raport z badań, Elbląska Rada Konsultacyjna Osób Niepełnosprawnych, Elbląg; http://www.erkon.elblag.com.pl/innowacyjnyerkon/ wp-content/uploads/2010/02/raport.pdf (data dostępu: 19.01.2014).

Dolny E., 2009, Popytowe bariery zatrudniania osób starszych, [w:] Wiśniewski Z. (red.), Zarzadzanie wiekiem w organizacjach wobec procesu starzenia się ludności, Towarzystwo Naukowe Organizacji i Kierownictwa „DOM ORGANIZATORA”, Toruń.

Dubas E., J. Pyżalski, M. Muszyński, J.R. Pavel (red.), 2008, Wspieranie rozwoju bezrobotnych 50+. Doświadczenia projektu Adults Mentoring, Wydawnictwo Uniwersytetu Łódzkiego, Łódź.

Duch-Krzysztoszek D., 2009, Praca płatna w życiu kobiet i mężczyzn, [w:] Szukalski P. (red.), Przygotowanie do starości. Polacy wobec starzenia się, ISP, Warszawa.

European Commission, 1999, Towards a Europe for All Ages, COM(1999) 221 final, Bruksela 21.05.1999.

European Commission, 2001, Draft Joint Employment Report, Commission Staff Working Paper, SEC(2001) 1398.

European Commission, 2012, Active ageing and gender equality policies. The employment and social inclusion of women and men of late working and early retirement age, http://ec.europa. eu/justice/gender-equality/files/2011_active_ageing_synthesis_report_en. pdf (data dostępu: 15.02.2014).

Giza-Poleszczuk A., 2008, Eksperci o dezaktywizacji, [w:] Giza-Poleszczuk A., M. Góra, J. Liwiński, U. Sztanderska, Dezaktywizacja osób $w$ wieku okotoemerytalnym. Raport z badań, MPiPS, Warszawa.

Giza-Poleszczuk A., M. Góra, J. Liwiński, U. Sztanderska,, 2008, Dezaktywizacja osób w wieku okotoemerytalnym. Raport z badań, MPiPS, Warszawa.

Gurria A., 2008, Living longer, working longer, The Journal AARP International, Washington.

GUS, 2012a, Osoby powyżej 50. roku życia na rynku pracy w $2010 \mathrm{r}$., Warszawa.

GUS, 2012b, Przeciętne miesięczne wynagrodzenie $w$ gospodarce narodowej $w$ latach 1950-2011 (podstawa wymiaru emerytur i rent), http://www.stat.gov.pl/gus/5840_1630_PLK_HTML.htm (data dostępu: 6.08.2013).

Hantrais L., 2004, Family policy matters. Responding to family change in Europe, The Policy Press, Bristol, [w:] P. Szukalski, J. Wiktorowicz, 2011, Koncepcja badań w zakresie rozwiazań promujących aktywne starzenie się $w$ wybranych krajach UE, Łódź, materiały wewnętrzne projektu „Wyrównywanie szans na rynku pracy dla osób 50+”.

Humphrey A., Costigan P., Pickering K., Stratford N., Barnes M., 2003, Factors affecting the labour market participation of older workers, Department for Work and Pension, Research Report no. 200, Huddersfield, http://praha.vupsv.cz/fulltext/ul_363.pdf (data dostępu: 9.08.2013).

Ilmarinen J., 2005, Towards a longer worklife! Ageing and the quality of worklife in the European Union, Finnish Institute of Occupational Health, Helsinki.

Kaleta D., T. Makowiec-Dąbrowska, A. Jegier, 2006, Lifestyle Index and Work Ability, International Journal of Occupational Medicine and Environmental Health, 19(3), s. 170-177.

Karpowicz E., 2010, Zarzadzanie pracownikami w wieku 50+ - perspektywa pracodawcy, Akademia Leona Koźmińskiego, Warszawa.

Kołodziejczyk-Olczak I., 2010, Career Plan 50+. Survey Report, SWSPiZ, Łódź. 
Kotowska I.E., K. Saczuk, P.A. Strzelecki, 2014, Rynek pracy [w:] I.E. Kotowska (red.), Rynek pracy $i$ wykluczenie społeczne w kontekście percepcji Polaków. Diagnoza Społeczna 2013. Raport tematyczny, Ministerstwo Pracy i Polityki Społecznej, Centrum Rozwoju Zasobów Ludzkich, Warszawa.

Kotowska I.E., I. Wóycicka (red.), 2008, Sprawowanie opieki oraz inne uwarunkowania podnoszenia aktywności zawodowej osób w starszym wieku produkcyjnym. Raport z badań. Ministerstwo Pracy i Polityki Społecznej, Warszawa.

Kowaleski J., P. Szukalski, 2008, Starzenie się ludności Polski - między demografia a gerontologia społeczna, Wydawnictwo Uniwersytetu Łódzkiego, Łódź.

Krajewski P. (red.), 2010, Osoby po 45. roku życia na rynku pracy Lubelszczyzny. Rekomendacje opracowane w ramach projektu, Fundacja CBOS, Warszawa.

Kryńska E., 2006, Wydtużanie życia zawodowego na polskim rynku pracy, „Polityka Społeczna”, $\mathrm{Nr} 9$.

Kryńska E., J. Krzyszkowski, B. Urbaniak, J. Wiktorowicz (red.), 2013, Diagnoza obecnej sytuacji kobiet i mężczyzn 50+ na rynku pracy w Polsce, Uniwersytet Łódzki, Łódź

Kryńska E., P. Szukalski (red.), 2013, Rozwiązania sprzyjające aktywnemu starzeniu się w wybranych krajach Unii Europejskiej. Raport końcowy, Uniwersytet Łódzki, Łódź.

Krzyszkowski J., 2010, Środowiskowa pomoc spoteczna wobec potrzeb ludzi starszych [w:] Być seniorem w województwie łódzkim, RCPS w Łodzi, Łódź.

Liwiński J., U. Sztanderska, 2010, Wstępne standardy zarządzania wiekiem w przedsiębiorstwach, Polska Agencja Rozwoju Przedsiębiorczości, Warszawa.

Maitland A., 2010, Working better. The over 50s, the new work generation, Equality and Human Rights Commission.

Maltby T., 2011, Extending Working Lives? Employability, Work Ability and Better Quality Working Lives, ,, Social Policy \& Society”, Cambridge University Press, vol. 10:3, s. 299-308.

Mossakowska M., A. Więcek, P. Błędowski, 2012, PolSenior. Aspekty medyczne, psychologiczne, socjologiczne i ekonomiczne starzenia się ludzi w Polsce, Termedia Wydawnictwa Medyczne, Poznań.

Munnell A.H., S. Sass, 2008, Working Longer. The Solution to the Retirement Income Challenge, Brookings Institution Press, Washington.

Perek-Białas J., H. Strzałkowska, K. Turek, 2010, Analiza desk research w ramach badań dot. stworzenia modelu świadczenia ustug doradztwa i rozwoju kariery pracowników 50+, Kraków.

Perek-Białas J., K. Turek, H. Strzałkowska, M. Kononowicz, J. Michałowska, M. Drozd-Garbacewicz, M. Jagiełło, 2011, Pracuję-rozwijam kompetencje. Innowacyjny model wsparcia dla pracowników $50+$. Zbiorczy raport z badań, PBS DGA, Sopot.

Perspektywa uczenia się przez całe życie z 10 września 2013 r., 2012, Międzyresortowy Zespół ds. uczenia się przez całe życie, Warszawa.

Podgórniak-Krzykacz A., J. Przywojska, 2011, Krajowe i regionalne programy rynku pracy wobec aktywizacji zawodowej osób $w$ wieku 50+/45+ [w:] B. Urbaniak, J. Wiktorowicz (red.), Raport $z$ analizy programów skierowanych do osób 50+ zrealizowanych $w$ Polsce $w$ latach 2004-2009 (s. 61-81), Uniwersytet Łódzki, Łódź.

Polska 2030. Trzecia fala nowoczesności. Dlugookresowa Strategia Rozwoju Kraju, Ministerstwo Administracji i Cyfryzacji, Warszawa, 11.01.2013.

Program Solidarność Pokoleń. Działania dla zwiększenia aktywności zawodowej osób w wieku 50+, Ministerstwo Pracy i Polityki Społecznej, Warszawa 2008.

Program Solidarność Pokoleń. Działania dla zwiększenia aktywności zawodowej osób w wieku 50+, Ministerstwo Pracy i Polityki Społecznej, Warszawa, grudzień 2013.

Raport. Starzejące się spoleczeństwo jako wyzwanie ekonomiczne dla europejskich gospodarek, 2011, Pracodawcy Rzeczypospolitej Polskiej, Amerykańska Izba Handlowa w Polsce, Warszawa, http://www.pracodawcyrp.pl/aktualnosci/art,782,jak-stawic-czola-wyzwaniu-starzejacego-siespoleczenstwa.html, (data dostępu: 10.04.2014 r.). 
Rzechowska E. (red.), 2010, Dojrzaly pracownik na rynku pracy: Perspektywa rozwojowa i perspektywa pracowników stużb społecznych (raport z badań), Lubelska Szkoła Biznesu, Lublin.

Sadowska-Snarska C. (red.), 2011, Uwarunkowania utrzymania aktywności zawodowej osób pracujących po 50. roku życia, Wydawnictwo Wyższej Szkoły Ekonomicznej w Białymstoku, Białystok.

Schimanek T., K. Trzos, M. Zatorska, 2011, Zarządzanie wiekiem - szansa dla przedsiębiorców. Miniprzewodnik zarzadzania wiekiem, Akademia Rozwoju Filantropii w Polsce, Warszawa.

Silcock D., 2012, Extending working lives, „Pensions”, vol. 17, s. 229-235.

Sobocka-Szczapa H. (red.), I. Poliwczak, 2011, Diagnoza sytuacji osób w wieku 45+ na rynku pracy $w$ Polsce $i$ wybranych krajach Unii Europejskiej. Aspekt ekonomiczny, Instytut Pracy i Spraw Socjalnych, Łódź.

Strategia Rozwoju Kapitału Ludzkiego 2020, Ministerstwo Pracy i Polityki Społecznej, Warszawa, czerwiec 2013.

Strategia Rozwoju Kraju 2020 - Aktywne spoleczeństwo, konkurencyjna gospodarka, sprawne państwo, Ministerstwo Rozwoju Regionalnego, Warszawa, wrzesień 2012.

Summary of the Peer Review on ,Extending working life: Tripartite co-operation and the role of the Centre for Senior Policy", Oslo, 24-25.05.2012.

Szaban J., 2010, Osoby 50+w wybranych badaniach krajowych i zagranicznych, Akademia Leona Koźmińskiego, Warszawa.

Szarota Z., 2010, Starzenie się i starość $w$ wymiarze instytucjonalnego wsparcia, Wydawnictwo Uniwersytetu Pedagogicznego, Kraków.

Szatur-Jaworska B., B. Rysz-Kowalczyk (red.), 2007, Rynek pracy a osoby bezrobotne 50+. Bariery i szanse, Akademia Rozwoju Filantropii w Polsce, Warszawa.

Szmidt C. (red.), 2012, Kompleksowy program aktywizacji osób starszych 50+. Raport końcowy, Akademia Leona Koźmińskiego, Millward Brown SMG/KRC, Warszawa.

Sztanderska U., 2008, Przyczyny wczesnej dezaktywizacji zawodowej i emerytalnej osób ubezpieczonych w ZUS [w:] Giza-Poleszczuk A., M. Góra, J. Liwiński, U. Sztanderska, Dezaktywizacja osób $w$ wieku okotoemerytalnym. Raport z badań, MPiPS, Warszawa.

Szubert Z., W. Sobala, 2005, Current determinants of early retirement among blue collar workers in Poland, International Journal of Occupational Medicine and Environmental Health, 18(2), s. $177-184$.

Szukalski P. (red.), 2008, To idzie starość - polityka spoteczna a przygotowanie do starzenia się ludności Polski, Wydawnictwo Instytutu Spraw Publicznych, Warszawa.

Szukalski P., 2006, Dezaktywizacja zawodowa Polek i Polaków na przedpolu starości, [w:] Z. Olejniczak (red.), Aktywność zawodowa i spoleczna osób z grupy wiekowej 50 plus. Opracowania, analizy, badania, dobre praktyki (s. 26-45), Wyższa Szkoła Marketingu i Zarządzania w Lesznie, Leszno.

Szukalski P., 2012, Solidarność pokoleń. Dylematy relacji międzypokoleniowych, Wydawnictwo Uniwersytetu Łódzkiego, Łódź.

Urbaniak B. (red.), 2007, Pracownicy 45+ w naszej firmie, UNDP, Warszawa.

Urbaniak B., 2011, Zatrudnienie i instytucje rynku pracy w warunkach starzejacych się zasobów pracy - badania dla Polski, Wydawnictwo Uniwersytetu Łódzkiego, Łódź.

Urbaniak B., J. Wiktorowicz (red.), 2011, Raport z analizy programów skierowanych do osób 50+ zrealizowanych $w$ Polsce $w$ latach 2004-2009, Uniwersytet Łódzki, Łódź.

Urbaniak B., J. Wiktorowicz, 2014, Support for Economic Activity of People Aged 50+ in Poland: the Best Solutions of the Goverment's Programme Solidarity of Generations, Comparative Economic Research. Central and Eastern Europe, vol. 17, no. 1/2014, s. 77-92.

Uścińska G., 2011, Diagnoza sytuacji osób w wieku 45+ na rynku pracy w Polsce $i$ w wybranych krajach UE na podstawie danych zastanych. Aspekt prawny, IPiSS, Warszawa.

Ustawa z dnia 11 maja 2012 r. o zmianie ustawy o emeryturach i rentach z Funduszu Ubezpieczeń Społecznych oraz niektórych innych ustaw, Dz.U. $2012 \mathrm{nr} 0$ poz. 637.

Ustawa z dnia 17 grudnia 1998 r. o emeryturach i rentach z Funduszu Ubezpieczeń Społecznych, Dz.U. $1998 \mathrm{nr} 162$ poz. 1118. 
Wydtużenie aktywności zawodowej czy przejście na emeryturę?...

Ustawa z dnia 19 grudnia 2008 r. o emeryturach pomostowych, Dz.U. z 2008 r. nr 237, poz. 1656.

Ustawa z dnia 28 marca 2008 r. o zmianie ustawy o emeryturach i rentach z Funduszu Ubezpieczeń Społecznych oraz niektórych innych ustaw, Dz.U. z 2008 r. nr 67, poz. 411.

Weyman A., D. Wainwright, R. O'Hara, Ph. Jones, A. Buckigham, 2012, Extending working life. Behaviuor change intervenstions, Department for Work and Pension, "Research Report", nr 809, Sheffield.

Wiktorowicz J., 2012, Stosunek pracujacych $w$ wieku 45+ wobec dalszego zatrudnienia, materiały wewnętrzne projektu „Wyrównywanie szans na rynku pracy dla osób 50+”, opracowane na podstawie wyników badania ilościowego osób w wieku 45+ Diagnozy obecnej sytuacji kobiet i mężczyzn 50+ na rynku pracy w Polsce, Łódź.

Wiktorowicz J. (red.), 2010, Fachowcy 45+, Społeczna Wyższa Szkoła Przedsiębiorczości i Zarządzania w Łodzi, Łódź.

Wiśniewski Z. (red), 2009, Determinanty aktywności zawodowej ludzi starszych, Wydawnictwo Dom Organizatora, Toruń.

Włodarczyk M., M. Paluszkiewicz, 2011, Formy prawne wyrównywania szans osób w wieku 50+/45+ na rynku pracy $w$ Polsce, [w:] B. Urbaniak, J. Wiktorowicz (red.), Raport z analizy programów skierowanych do osób 50+ zrealizowanych w Polsce w latach 2004-2009 (s. 35-51), Uniwersytet Łódzki, Łódź.

Woszczyk P. (red.), 2011, Zarządzanie pracownikami 50+. Teoria i praktyka, HRP, Łódź.

Wysokińska Z., 2013, Koncepcja aktywnego starzenia się - o próbach jej wdrażania w UE [w:] Kryńska E., P. Szukalski (red.), Rozwiqzania sprzyjające aktywnemu starzeniu się w wybranych krajach Unii Europejskiej. Raport końcowy, Uniwersytet Łódzki, Łódź.

Zawadzki K., 2009, Zarządzanie wiekiem w organizacjach gospodarczych, [w:] Wiśniewski Z. (red.), Zarzadzanie wiekiem $w$ organizacjach wobec procesu starzenia się ludności, Towarzystwo Naukowe Organizacji i Kierownictwa „DOM ORGANIZATORA”, Torun.

\title{
EXTENDING WORKING LIFE OR RETIRING? A MICROECONOMIC STUDY
}

\begin{abstract}
The ageing of societies has recently become one the most important phenomena shaping social policy in Poland and other developed countries. At the same time, it is becoming increasingly clear that ageing should not be perceived only in terms of threats. Silver economy, age management, and lifelong learning are the notions that become acknowledged by various labour market and social policy stakeholders. The rationale behind these ideas is to make the best use of the potential of people around the retirement, in line with the life cycle concept, but also of new social needs that arise with an increasing proportion of people aged 50+ in the society, and with considerably improving quality of their lives.

The discussion presented in the article is limited to problems in extending working life of Poles. The aim of this paper is analysis of the factors influencing the
\end{abstract}


extension of the working life in Poland, from an individual perspective, i.e. by looking at the reasons of individual decisions of people close to the retirement age. The article is both theoretical and empirical in nature, presenting a review of studies including the support for the economic activity of "older" workers, coupled with the outcomes of a statistical analysis carried out in the project „Equal opportunities in the labour market for people aged 50+".

Keywords: economic activity, ageing, social policy 